Florida International University

FIU Digital Commons

FIU Electronic Theses and Dissertations

University Graduate School

3-28-2019

\title{
Negotiating with Patriarchy: Women, Sexuality, and Power in Yoruba Sacred Oral Genres.
}

Ajoke Adebisi

Florida International University, aadeb010@fiu.edu

Follow this and additional works at: https://digitalcommons.fiu.edu/etd

Part of the Africana Studies Commons, Religion Commons, and the Women's Studies Commons

\section{Recommended Citation}

Adebisi, Ajoke, "Negotiating with Patriarchy: Women, Sexuality, and Power in Yoruba Sacred Oral Genres." (2019). FIU Electronic Theses and Dissertations. 4012.

https://digitalcommons.fiu.edu/etd/4012

This work is brought to you for free and open access by the University Graduate School at FIU Digital Commons. It has been accepted for inclusion in FIU Electronic Theses and Dissertations by an authorized administrator of FIU Digital Commons. For more information, please contact dcc@fiu.edu. 


\section{FLORIDA INTERNATIONAL UNIVERSITY}

Miami, Florida

NEGOTIATING WITH PATRIARCHY: WOMEN, SEXUALITY, AND POWER IN YORUBA SACRED ORAL GENRES.

A thesis submitted in partial fulfillment of the requirement for the degree of

MASTER OF ARTS

in

RELIGIOUS STUDIES

by

Ajoke Adebisi

2019 
To: Dean John F. Stack, Jr.

Steven J. Green School of International and Public Affairs

This thesis, written by Ajoke Adebisi, and entitled Negotiating with Patriarchy: Women, Sexuality, and Power in Yoruba Sacred Oral Genres, having been approved in respect to style and intellectual content, is referred to you for judgment.

We have read this thesis and recommend that it be approved.

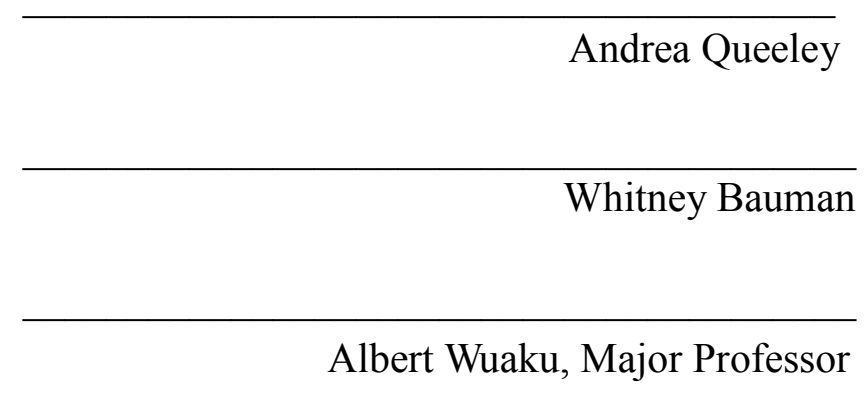

Date of Defense: March 28, 2019

The thesis of Ajoke Adebisi is approved.

Dean John F. Stack, Jr.

Steven J Green School of International and Public Affairs

Andrés G. Gil

Vice President for Research and Economic Development and Dean of the University Graduate School

Florida International University, 2019 


\section{ACKNOWLEDGMENT}

Thanks be to the Almighty God who always causes us to triumph.

Deepest gratitude goes to:

Mr. Mojeed Adebisi, Mrs Kikelomo Adebisi, Mrs Adija Igun, Mrs Aola, Mr Taju Adebisi, Mr Akeem Adebisi, Mr. S.M.O and Mrs. Betty Adebisi, Dr. Omotayo and Mr. Akinsola Akinfemiwa, Aunty Dupe, Aunty Tosin, Professor Jacob Olupona, Professor Albert Wuaku, Professor Andrea Queeley, Professor Whitney Bauman, Professor Adekunle Dada, Professor Eric Larson, Prof. Michaela Moura Koçoglu, Department of Religious Studies at FIU, Ms. Luz Aviles, Ms. Yusimi Sayus, English Department at FIU, Bosola Kehinde, Yewande Fadojutimi, Ms. Olaitan, and Mojisola Adebisi. 


\begin{abstract}
OF THE THESIS
NEGOTIATING WITH PATRIARCHY: WOMEN, SEXUALITY, AND POWER IN

YORUBA SACRED ORAL GENRES.
\end{abstract}

by

Ajoke Adebisi

Florida International University, 2019

Miami, Florida

Professor Albert Wuaku, Major Professor

This study argues that Yoruba oral genres offer women models "of "and "for" ways of enduring resistance from patriarchy. In the myths, proverbs and praise poems, women challenge marginalization in ways incomparable to what prevails in other world religions. By engaging Yoruba oral genres, this study offers insights into how the Yoruba reflect on sharing of power among the male and the female. The study also highlights how Yoruba oral genres speak to the power imbalance in male /female relationships and sheds light on the prescriptions oral genres offer women for negotiating these imbalances. 


\section{TABLE OF CONTENTS}

CHAPTER

PAGE

I. GENERAL INTRODUCTION .1

\section{LITERATURE REVIEW AND CONTRIBUTION OF THE STUDY}

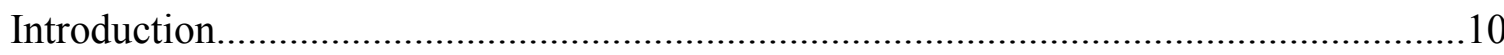

Western Bias and Yoruba Gender Notion.................................................................12

Sex and the Power of Yoruba Women in the Oral Tradition........................... 18

How Women Negotiate with Patriarchy in Yoruba Oral Genres..................................22

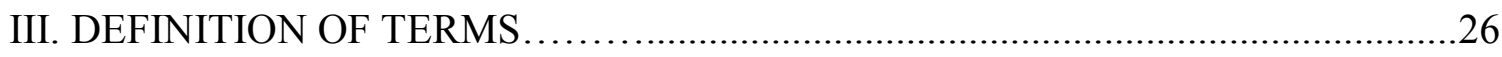

Texts and Contexts of the Yoruba Oral Traditions.................................................26

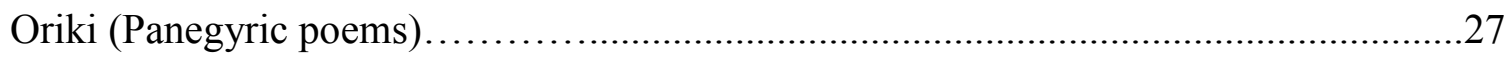

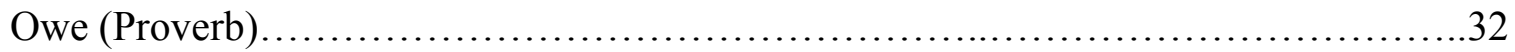

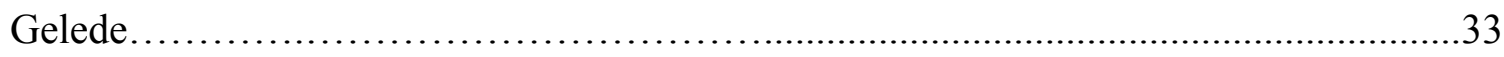

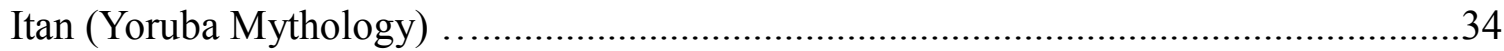

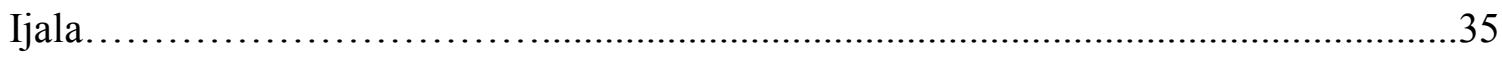

IV. GENDER IDEOLOGIES AS EXPRESSED THROUGH YORUBA MYTHOLOGY ........................................................... 38

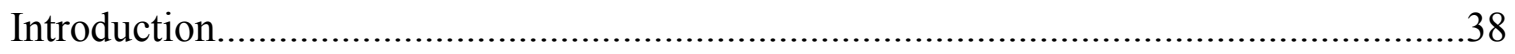

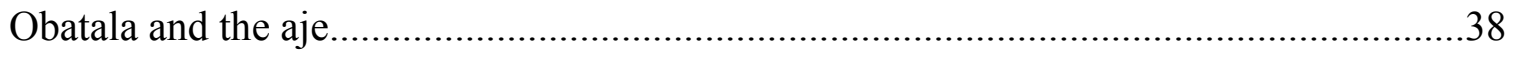

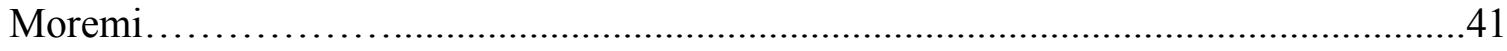

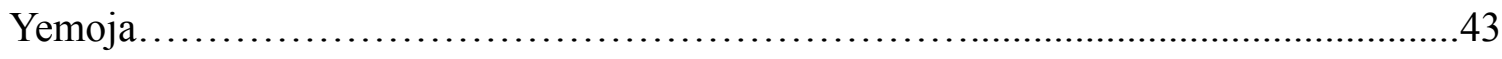

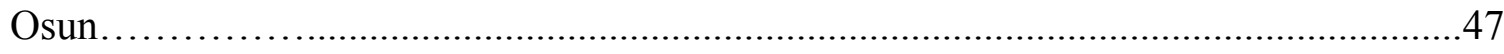

V. PROVERBS AS SOURCES OF YORUBA GENDERS NOTIONS ..................53

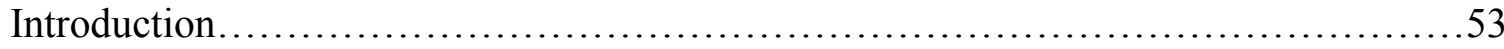

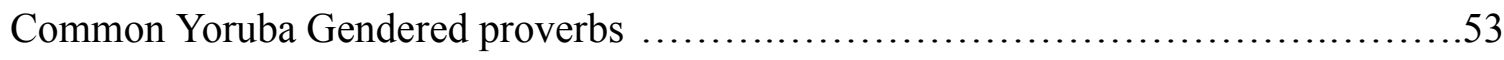

Conclusion................................................................ 61

VI. NEGOTIATING WITH PATRIARCHY: ORIKI AS WINDOWS INTO GENDER IDEOLOGIES AMONG THE YORUBA.......................................63 


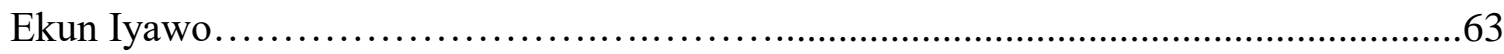

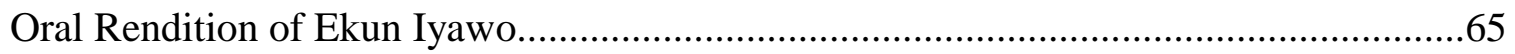

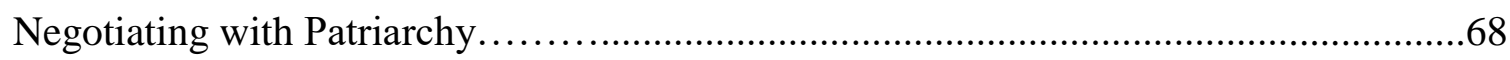

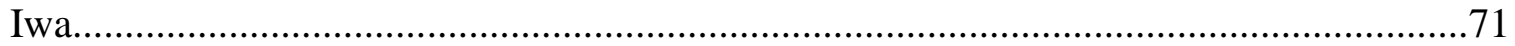

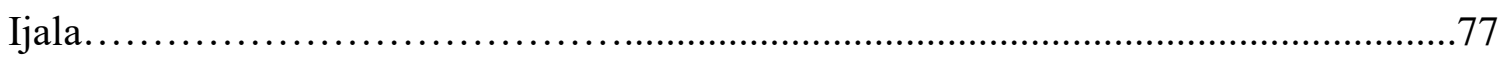

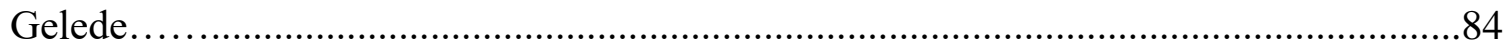

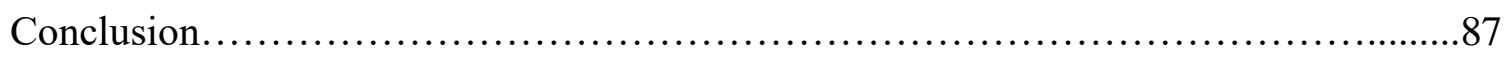

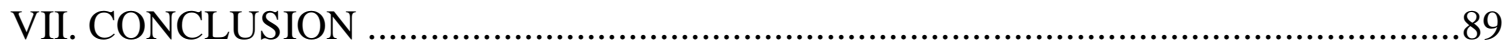

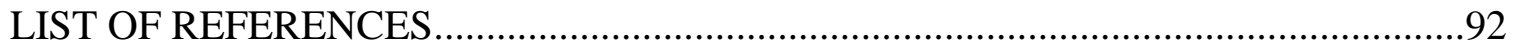




\section{CHAPTER I}

\section{GENERAL INTRODUCTION}

There is an ongoing discourse/debate on gender taking shape in the study of the Yoruba and their extensions in the African Diasporas. This was started by a generation of African scholars (e.g. Amadiume 1997, Nzegwu 2001, Okome 2001) located primarily in western institutions who, have begun to question the explanatory power of gender in African societies. In a controversial work entitled The Invention of Women: Making an African Sense of Western Gender Discourses, one of these scholars, the US-based Nigerian theorist, Oyewumi, argues that the biological sex difference, which structures social relations in Euro-American culture, is irrelevant in many African societies ${ }^{1}$. Focusing on the Oyo-Yoruba of southwestern Nigeria, Oyewumi argues that gender distinction is not coded within Yoruba language and social practice and biology does not determine or influence social relations, access to power, or a person's participation in institutions. She claims, in place of gender, seniority is a key organizing principle in Oyo-Yoruba.

Oyewumi's overall project marked a shift in the debate on gender away from a deterministic focus on biology, to the primacy of gender structuration in social relations. She emphasizes the need for scholars to be sensitive to the categories and concepts that are important to specific cultures in analyses of gender. While Oyewumi relies on Yoruba language and discourse to make her case, Deidre Badejo (1996), examines the myths and meanings of Osun, a Yoruba goddess whose power base resides on her femininity and wealth. Using fieldwork and original sources, Badejo challenges scholars to explore the intersection of gender and spirituality, that is, how spiritual

\footnotetext{
${ }^{1}$ Oyěwùmí, Oyèrónké (1997). The Invention of Women: Making an African Sense of Western Gender Discourses. London: University of Minnesota Press
} 
concepts and practices of the Yoruba can inform us about indigenous understandings of gender, especially the female. Similarly, drawing on a wide range of oral and written sources, Oyeronke Olajubu demonstrates how women occupy a central place in the religious worldview and life of the Yoruba people, and shows how this understanding informs how both women and men engage in mutually beneficial roles in the Yoruba religious sphere. She also illuminates the tensions between the prominent roles of Yoruba women in religion and their perceived marginalization in society, emphasizing how Yoruba women have challenged their marginalization in ways unprecedented in other world religions.

The present study builds on these earlier studies. Especially, this study follows these leads and seeks to tease out Yoruba understandings of gender from oriki (panegyric poems), owe (proverbs), and itan (myths). This study explores these oral genres, paying attention to what they teach us about the female, the male, and male /female relationships in Yoruba thinking. A fundamental assumption of the study is that as repositories of Yoruba traditional, secular, and religious ideas, oral genres offer keen insights into how the Yoruba think of their world. The study interprets and analyzes renditions of Yoruba Ifa oral texts. These include owe, oriki and itan. The goal of this exercise is to illustrate how the genres reflect on the struggles of the Yoruba woman in a patriarchal society that offers little or no reward for her labor and how these same genres offer models "of" and "for" the ways in which the Yoruba woman can survive patriarchy. The main argument of the study is that Yoruba oral genres offer women models "of" what society expects of them and models "for" ways of enduring resistance from patriarchy. By engaging Yoruba oral genres, we gain insights into how the Yoruba 
reflect on sharing of power among women and men. Yoruba oral genres also speak to the power imbalance in male /female relationships and sheds light on the cultural prescriptions the Yoruba offer women for negotiating these imbalances.

The rationale for focusing on Yoruba oral literature in this project is that literature reflects gender inequality and is also one of the instruments through which gender inequality is reproduced in the Yoruba as well as in any other tradition. For instance, Laura L. O’Toole (2007) highlights how men are led by dominant culture to be aggressive sexually, that is, to expect sex on demand (p.214). Also, Ijala, an oriki rendered for hunters, is another literature (oral) that demonstrates men's expectation from women and their response to women's failure to meet such gender role requirements. The authority ascribed to these oral sources as representing events that happened in the past, as well as the significance the elderly attach to them as the repositories of traditional knowledge, make the unequal gender relations reflected in them enforceable in the Yoruba culture. As the elderly represent the purveyors of traditional knowledge, children emulate them and become socialized into the gender roles and their hierarchies. Oral genres play a crucial role in this socialization process. For instance, the Yoruba use proverbs to correct behaviors they consider to be reprehensible.

And as will be demonstrated in the chapters of the study, the Yoruba gender hierarchy depends on many factors and these factors shape women's consciousness and how they approach survival in a culture in which the balance of power seems to tilt more towards men. The roles of women and men are also defined in the genres. While polygamy is valued in the Yoruba oral literature, there would seem to be a silence on 
polyandry. Women's access to power comes at the expense of their overcoming inconvenient situations. This makes Yoruba patriarchal ideology seem subtle as women were not totally denied access to power. For instance, in a polygamous family, elderly women exert considerable power and influence while the newly wedded brides' power is very limited as they have to contend with the family constraints. These factors complicate patriarchy as they shift the focus from the hierarchical relationship between men and women to hierarchy within the polygamous household.

This study demonstrates how the Yoruba society institutionalizes gender inequality through its cultural values. As we will glean from the oral genres in this study, Yoruba culture expects so much from women, and such expectations constitute legitimizations of violence or oppression in the society as identified in the oriki, owe, and itan.

The focus of this study is on the Ifa literary corpus. It explores what this corpus teaches us about Yoruba understandings of how they should think and perform gender. A repository of Yoruba traditional secular and religious knowledge, the 256 odu, Ifa literary corpus, embodies myths, proverbs, songs, Oriki (praise poems) and other oral genres that offer keen insights into how the Yoruba think of their world. It follows then, that this study is also a reconstruction of the ideological basis of the ways in which the Yoruba performs gender and it achieves this goal by interpreting selections of the proverbs, myths, praise poetry, and other oral texts. For example, as we will see in the chapters that follow, that in ekun iyawo (bridal lamentations and tears); the bride is seen lamenting her new position of marriage on the eve of her wedding day. As Barber (1991) illustrates in her work, this day is also the bride's day to enjoy. It would seem 
intriguing to conceive of a woman having just one enjoyment day in which she commands the presence of her well-wishers by enjoying her own performance of the bridal oriki for them. As Barber observes, the bride's enjoyment day is to enjoin those who came to watch her as witnesses to such a day - the day that she was still a virgin. The proverbs, myths, ekun iyawo, and other oriki, point us to how the Yoruba are expected to perform gender. Finally, this study presents selections of Yoruba texts that counter the popular argument that the Yoruba language is androgynous. It maintains that gender does not have to be coded in the Yoruba language before it is entrenched in the culture. The Yoruba were performing gender before the Western presence. A myth demonstrating how the male gods sidestepped Osun, a goddess, during the creation of the universe illustrates this point.

\section{Theoretical Frameworks}

\section{Geertz's Implied Communicator of Meanings}

In this section I discuss the relevant theoretical ideas I engage in this study. I will discuss them independently and then in terms of how we can put them together as a coherent frame of relevant theoretical ideas. One of these theoretical ideas is Geertz's concept of religion as a cultural system. According to Geertz (1973), we must treat culture as a text that must be interpreted. He asserts that the purpose of analyzing culture is to help us engage in an interpretive journey to arrive at its meanings:

The concept of culture I espouse, and whose utility the essays below attempt to demonstrate, is essentially a semiotic one. Believing, with Max Weber, that man is an 
animal suspended in webs of significance he himself has spun, I take culture to be those webs, and the analysis of it to be therefore not an experimental science in search of law but an interpretive one in search of meaning. It is explication I am after, construing social expressions on their surface enigmatical. But this pronouncement, a doctrine in a clause, demands itself some explication. ${ }^{2}$

Identifying religion as an integral portion of culture, Geertz defines it as a system of "symbols which act to establish powerful, pervasive and long-lasting moods and motivations in men by formulating conceptions of a general order of existence and clothing these conceptions with such an aura of factuality that the moods and motivations seems uniquely realistic. ${ }^{3 "}$ Geertz maintains that as a system or cluster of symbols religion or sacred symbols are important in two related ways. It reflects peoples' understandings of their worlds on the one hand, and on the other, shape them to the happenings in their worlds. This study views the oral genres it explores from this perspective. They are cultural symbols in the "Geertzian" sense, and as such, they function as vehicles through which the Yoruba communicate deeper meanings. These meanings offer us insights into how the Yoruba understand their world on the one hand. On the other hand, these meanings give us a sense of the ideologies that inform how the Yoruba think and act as they shape themselves to happenings in their world. In the chapters that follow, I will demonstrate the Yoruba understandings of gender, gender

\footnotetext{
${ }^{2}$ Geertz, Clifford. (1973). The Interpretation of Cultures: Selected Essays. New York: Basic Books p.2

${ }^{3}$ Geertz, Clifford. (1973). The Interpretation of Cultures: Selected Essays. New York: Basic Books p.90
} 
relations, and expectations that are conveyed to us by the oral genres. Where necessary, I will also show how the actions of the actors in oral narratives such as myths offer us insights into Yoruba expectations of how males and females ought to behave in responding to specific life situations. In a sense, I argue that these genres are like Yoruba texts that offer models of the Yoruba gendered world and models for how to live in this world as women and men.

\section{Control, Exploitation, and Resistance}

Scott's (1985) work Weapons of the Weak is a fieldwork-based study

demonstrating how subordinate classes develop strategic devices in defending themselves in class struggles over material resources. Scott's research offers valuable leads in this study as it helps us in conceptualizing how the Yoruba female actors in the oral genres presented in the study navigate the patriarchal system through a myriad of strategies. In Scott's study, he shows how class hierarchy is broken down into the rich, middle- and poor-income earners. The advancement of mechanized farming favors monopoly of lands by the rich. Subjects, that is, those whose livelihood depends on manual labor are exposed to perilous situations. The elements from this subordinate category use resistance as means to control the power of the superordinate over material resources. Nevertheless, their ways of resisting the hegemony must take very subtle forms because of their weaker structural positions. Scott lists the cultural devices these categories use to resist the hegemony and refers to them as "every day weapons of the weak." These measures include "foot-dragging, dissimilitude, fake compliance, pilfering, feigned 


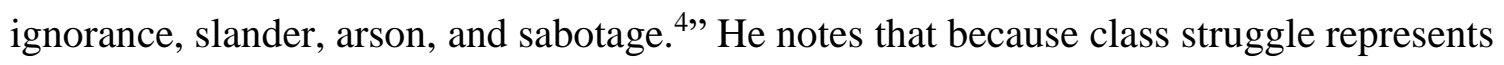
an occasion of interaction between the classless and the classed, complicity and quiet evasiveness must influence the lower-class struggle with the upper class. ${ }^{5}$ Scott argues that these ways of resisting are more effective than the struggles characterized by massive and deviant confrontations (Scott, 1985). In other words, subordinates deploy these effective bargaining strategies in negotiations with superordinate groups.

Scott's notion of "everyday forms of resistance" offers us leads in understanding the prescriptions for how Yoruba women must act in their negotiations with Yoruba patriarchy as demonstrated in the oral genres such as myths and proverbs. In the chapters that follow, we will read about how the female actors presented in these genres deploy a variety of weapons of the weak in their dealings with Yoruba patriarchy. Because we are dealing with oral narratives here, we must treat the actions of the women as mere cultural prescriptions for how women ought to respond in the different contexts in which they confront patriarchy in the Yoruba understanding. The genres presented in this study must be understood as Yoruba symbolic cultural forms offering among other things, models of Yoruba understandings of their gendered realities, and models for how one, especially women, can negotiate this Yoruba gendered world. Women, who constitute a subordinate category in this world, survive by deploying a variety of negotiating strategies. In the genres I explore, we find cultural prescriptions for the tactic women can use in

\footnotetext{
${ }^{4}$ Scott, James C. (1985). Weapons of the Weak: Everyday Forms of Peasant Resistance. New Haven: Yale University Press p.29

${ }^{5}$ Scott, James C. (1985). Weapons of the Weak: Everyday Forms of Peasant Resistance. New Haven: Yale University Press
} 
responding to power imbalance. Geertz's analysis of religion helps us to understand the genres as Yoruba cultural symbols, offering Yoruba understandings of gender and gender relations on the one hand. On the other hand, Scott's analysis of the subtle and nonviolent ways in which the structurally weak in society negotiate with hegemonies, offers us a way of theorizing the actions of the female actors as they bargain with patriarchy, in the narratives and depictions of these genres.

\section{Structure of Study}

Chapter I is the introduction. Chapter II reviews the existing literature and discusses the themes in the emerging academic discourse on gender in Africa, especially among the Yoruba. Chapter III presents a brief introduction to the oral genres to be interpreted in this study. It also discusses the theoretical models that this study intends to engage. Chapter IV examines gender ideologies as expressed through mythology. Chapter V examines proverbs as sources of Yoruba genders notions. Chapter VI examines Oriki and everyday statements as windows into how Yoruba people think about gender. Chapter VII concludes the study by tying together the threads that run through the arguments presented in the chapters. 


\section{Chapter II \\ LITERATURE REVIEW AND CONTRIBUTION OF THE STUDY}

The study of women in religion by women has grown in recent times in comparison with earlier scholarly writings on religion that witnessed predominantly fewer women scholars. Petro (2012) asserts that American history of religion, which was primarily focused on Protestantism, was predominated by men in the 1970's. The study of African women in religion is not an exception. In Nigerian Women in Historical Perspective, Bolanle Awe (1992), a Nigerian historian, identifies the immense challenges women's studies faced in the 1970s as an area of academic focus. Awe demonstrates using oral and historical sources how the exclusive focus on men's achievement in the historical literature, obscures the public achievements of women. Similarly, in his reference to women and gender, Olupona (1996) briefly comments on how women scholars of religion in America as well as Nigeria are marginalized in the academy. It can be assumed from Olupona's stance that the dearth of women scholarship in religion might influence the quality of the literature written about women. Questions such as "Why are women's exploits attributed to men in historical records?"” are significant to this study. In this chapter, I review the available literature on women, sexuality, and power in the Yoruba tradition. I do so by examining what both male and female authors have written thus far on gender relations in African religions.

In the Invention of Africa: Gnosis, Philosophy, and the Order of Knowledge, V.Y Mudimbe (1998), describes "Africanizing knowledge" as one of the tools scholars can

\footnotetext{
${ }^{6}$ Navarro, Marysa. 1999. Women in Latin America and the Caribbean: Restoring Women to History. Eds. Marysa Navarro and Virginia Sanchez
} 
engage to render an undiluted African interpretation in writing. Scholars have highlighted the contradictory perceptions of African women in literature and how external factors play a part in heightening these perceptions. Andrea Cornwall (2005) identifies how literature that focused on African gender studies are from two perspectives, women as powerless, and women as assertive. Cornwall states that these contradictions are traceable to the colonial period in Africa, citing the works of Mohanty (1988) as well as Newell (1996) to explain the contradictory representation of African women in literature. Cornwall also highlights how the conventional feminist ideas intersect with the contemporary writings on women. Citing examples from feminist scholars like Mohanty (1988), Cornwall points out the contradictory representations of African women in literature. She claims that such representations are partially influenced by external factors such as Western depictions of African women as being subservient to men.

In Olodumare: God in Yoruba Belief, Bolaji Idowu (1994) also suggests that scholars remain objective in their presentation of evidence. Idowu suggests that scholars should beware of that which is "alluringly clamorous and fanciful in the quest of searching for the truth." Idowu further states that some foreign descriptions of African traditions render inauthentic descriptions. It is from this critical perspective that this research engages literature on African oral traditions to deconstruct African indigenous notion of gender. Specifically, this study focuses on the Yoruba of Nigeria. There is scanty literature on women and gender in Yoruba oral traditions.

\footnotetext{
${ }^{7}$ Idowu, E. Bọlaji. (1994; 1995). Olódùmarè: God in Yorùbá Belief. New York, NY: Wazobia
} 
Through an exploration of the three emerging themes, Western bias and Yoruba gender notions; Sex and the power of Yoruba women in the oral tradition; and how women negotiate with patriarchy in Yoruba tradition, this study adds to the conversation on women, sexuality, and power by focusing on the Yoruba of Southern Nigeria. A number of scholars have demonstrated how culture can serve as an instrument in the defining of gender in a society. I define culture in this study as the way of life of a people. Kolawole (1998) asserts that, in Nigeria, a number of women readily accept or see themselves through how the culture positions them. Myth informs these existing conceptions of people's culture. Myth is one of the ways through which gender perceptions are entrenched in the society. This chapter will review available literature on themes emerging from the topic for research, "Negotiating with Patriarchy: Women, Sexuality, and Power in Yoruba Sacred Oral Genres." The aim of this study is to explore pressing issues in gender, power, and gender relations in Yoruba panegyric poems, proverbs, and myths.

\section{Western Bias and Yoruba Gender Notion.}

The focus in the literature available on gender in the Yoruba religious studies includes the quality of relationship between women and men and their power relations in the society. Although the literature that focuses exclusively on gender in Yoruba is scanty, there have been some significant studies in Yoruba gender studies recently. In most cases, gender is not the focus of this literature but often a reference point. While some literature on Yoruba gender relations present Yoruba women as powerful, others present these women as complementing men in social and political arenas, or as subservient to men. Some of these scholars identify gender complementarity as a 
weakness, while others share a different view. Other literature seeks to draw on insights from how Western analytical modes of interpretation should not be taken as universal tools for investigating non-Western traditions.

Oyewumi (1997) argues that the Western gender language is not coded in the Yoruba tradition and social categories, such as men and women, were imposed upon the Yoruba culture and they do not exist in Yoruba thinking. ${ }^{8}$ Oyewumi maintains that Western influence in Yoruba historiography distorts the history itself since sex categories like men and women were invented during the translation of some Yoruba texts into English (1997).

She notes:

Gender was not an organizing principle. Seniority defined by relative age was the dominant principle. Thus, social categories deriving from an elaboration of anatomic distinctions - categories were gender-free in that the anatomy did not constitute the basis for their construction and elaboration. Access to power, exercise of authority, and membership in occupations all derived from the lineage, which was regulated from within by age, not sex ${ }^{9}$.

\footnotetext{
${ }^{8}$ Oyěwùmí, Oyèrónké (1997). The Invention of Women: Making an African Sense of Western Gender Discourses. London: University of Minnesota Press p.83

${ }^{9}$ Oyěwùmí, Oyèrónké (1997). The Invention of Women: Making an African Sense of Western Gender Discourses. London: University of Minnesota Press p.83
} 
While challenging patriarchy, the author surveys the documentation of the old Oyo history to question the representation of men in prominent positions such as kings rather than women ${ }^{10}$. Oyewumi claims that there was no linguistic parameter for distinguishing the sex of a person in Oyo Yoruba and the naming of women and men is a Western construct. Oyewumi emphasizes that the West assumes a universal category for the study of gender. She suggests that women could have held prominent positions such as kings and ruled independently instead of functioning as the subordinate (p.85).

Connell's (2005) explication of the European culture before the eighteenth century, which she described as the culture that regards women as being different from men because of inferiority, corroborates Oyewumi's argument ${ }^{11}$. Indeed, there is a sense in which we can say that Yoruba women are not inferior in the ways Western women were portrayed to be. Yoruba women could function independently without the men.

In "Visualizing the Body: Western Theories and African Subjects," Oyewumi (2005) argues that previous scholarship privilege Western theorists who promote the idea of the female inferior other. According to her, this distinction is replicated in race, class, gender, etc. Highlighting the flaw inherent in the Western idea of somatocentricity, a cultural system of social organization that rests on biological determinism, Oyewumi identifies the flaws, but falls into a similar trap by generalizing that seniority is the order of social relationships amongst the Oyo-Yoruba. For this reason, her argument is not

\footnotetext{
${ }^{10}$ Oyěwùmí, Oyèrónké (1997). The Invention of Women: Making an African Sense of Western Gender Discourses. London: University of Minnesota Press p.85

${ }^{11}$ Oyěwùmí, Oyèrónké (1997). The Invention of Women: Making an African Sense of Western Gender Discourses. London: University of Minnesota Press p.252-253
} 
valid because what she says of the Yoruba can also be said of western understandings. Oyewumi fails to identify how the usage of the English words, "aunty" or "uncle," among the present-day Yoruba is not adopted for the primary purpose of identifying the sibling of one's parents alone, and how this sign of respect functions in a social setting with people who may not even be related by blood in Yoruba. Despite there being a Yoruba vocabulary for the younger and the elder one, e.g. aburo and egbon with the usage of "e" and "o," the Yoruba lacks the vocabulary of seniority, for an aunty or uncle, as well as for the non-blood related people. Additionally, Yoruba gender hierarchy is not coded in the Yoruba language, rather it is coded in its performance. This performance can vividly be identified at the Yoruba preference of the birth of a male child (ako) to the female (abo). While a woman with a male child is highly honored, the birth of a female does not receive the same regard accorded to the male. In the subsequent chapters, one of the proverbs on kumolu aptly explains this concept and praxis.

If approached from the angle of the vision from which Oyewumi addresses Yoruba gender ideology, Oyewumi's unsubstantiated assumptions about her rhetoric of seniority suggests that the idea of seniority itself could be a Western idea. If seniority were originally a Yoruba idea, the usage of the English words, aunty or uncle for demonstrating hierarchies would be unnecessary. However, language alone does not establish the authenticity of a people's way of life in the Yoruba and other cultural systems. Other factors must be considered. The fact that Orunmila and other Yoruba divinities had multiple wives who they considered subordinate suggests that the male and female hierarchical relationships were not introduced into the Yoruba indigenous tradition. It is an indication of the authenticity of patriarchy as a feature of Yoruba 
culture. Oyewumi's work is important to this study because it provides evidence that counters her main positions about gender among the Yoruba. This study therefore builds upon Oyewumi's ideas as well as bridge gaps highlighted in her work in subsequent chapters.

Another body of writing that engages the Western stereotypes in Yoruba representation examines the discrepancies in how Yoruba translations are rendered in English. In "The Good the Bad and the Beautiful," Hallen (2000) presents a comprehensive examination of imo (the indigenous Yoruba knowledge) by looking into the Western representations of Yoruba etymological ideas. Hallen's quest is to bring together the epistemic as well as the aesthetics of the Yoruba indigenous knowledge. In his exposition, Hallen refers to how English translations of some Yoruba words have corrupted instead of corroborating the Yoruba indigenous knowledge. A very good example is the word "aje" which is commonly translated in English as a "witch." Halen questions the Western scholarly reduction of the term, aje, to witches. The terminology of aje, according to Hallen, carries a more positive meaning than the connotation of witchcraft. Hallen asserts that such hasty interpretation brings about derogatory and demeaning elements that distorts intercultural communication and respect. ${ }^{12}$

Hallen presents two meanings of aje, confirming how Yoruba approaches to interpretation are not linear. According to Hallen, aje signifies different personality types who are mainly natural human beings that possess extraordinary intelligence rather than just possessing spiritual power. Hallen opines that since the Yoruba society also

\footnotetext{
${ }^{12}$ Hallen, Barry. (2000). The Good, the Bad, and the Beautiful: Discourse about Values in Yoruba Culture. Bloomington: Indiana University Press p.86-91
} 
conceives of aje in a contradictory way, it is not surprising that most people called aje are women. Hallen demonstrates that just like women, men can also either be benevolent or malevolent aje. ${ }^{13}$ Hallen's concept of a male aje seems to align with Oyewumi's stance that women's exploits could have been attributed to men among the Yoruba. In this way, the idea of a male aje would suggest something of a role reversal. However, Hallen fails to identify where the Yoruba stereotyping of aje emanates from. This leaves a gap, leading us to wonder whether the stereotyping of aje as a witch was due to errors in translation or linked to the Yoruba original gendered meanings of the term.

Similarly, Velma E. Love's (2012) ethnography on the Oyotunji village of Ifa devotees offers another intriguing take on the issue of aje. Love argues that aje is the feminine power that recreates the world. Love highlights that understanding aje as an idea capturing motherhood is crucial. Love provides information on how the sacred Odu Ifa emanates from the "great mothers" also known as aje or "iya mi" meaning "my mother." Love maintains that as a source of power, aje can refer to spiritual power or a powerful woman without negative meaning. ${ }^{14}$ Thus, as Love puts it, an aje has to be careful in her thinking because of her ability to make things happen. However, Love brings out the paradoxes in the interpretation of aje noted by Wande Abimbola who claims that aje can either be malevolent or benevolent. Abimbola notes how Ifa literature presents women as

\footnotetext{
${ }^{13}$ Hallen, Barry. (2000). The Good, the Bad, and the Beautiful: Discourse about Values in Yoruba Culture. Bloomington: Indiana University Press p.91

${ }^{14}$ Love, Velma E. (2012). Divining the Self: a study in Yoruba Myth and Human Consciousness. University Park, Pa: Pennsylvania State University Press p.81
} 
aje who are "bloodsucking, wicked and dreadful. ${ }^{15 "}$ In other words, Abimbola confirms that aje can also be regarded in the normative terms of witchcraft. However, Love maintains that the derogating as well as the praising of women are meant to bring balance to the universe. In examining the goddesses in the Yoruba mythology, Love argues that aje is the feminine principles that recreate the world. While Allen maintains that aje as a witch is a distortion of the Yoruba meaning, Love's argument focuses on the malevolent and benevolent power that aje brings. One of the goals of this current study is to contribute to this debate by looking into the concept of aje in the Yoruba mythology in order to understand their portrayal as "witches" on the one hand, and as the balance that recreates the universe as argued by Love on the other.

\section{Sex and the Power of Yoruba Women in the Oral Tradition}

A body of writings also focuses on relationships among the sexes in the Yoruba tradition. The key theme here is how Yoruba women experience patriarchy. Among such literature is Sex and the Empire that is No More: Gender and the Politics of Metaphor where Lorand Matory (1994) presents contrasting gender images. In this work, Matory draws upon some metaphors from the possession gods and gigun "mounting," which he claims signify spirit possession as well as sexual conquering. The author also highlights males (e.g. the elegun, or male masquerades) whose dress style expresses how the Yoruba conceives of the male or the female. From an etic standpoint, Matory demonstrates how elegun adorn themselves in earrings and weave their hair as travesties.

\footnotetext{
${ }^{15}$ Love, Velma E. (2012). Divining the Self: a study in Yoruba Myth and Human Consciousness. University Park, Pa: Pennsylvania State University Press p.82
} 
Matory not only brings out the complementary roles of Yoruba men and women in this regard, but also highlights some of the areas that the so called "complementarity" might be marginalizing a Yoruba woman and suggests further research in this area.

Matory identifies the significant place that Yoruba women hold, stressing how we should not undermine the political and economic roles of Yoruba women. Matory situates the contextual distinction of the male transvestite as "existing gender categories" in Oyo Yoruba tradition. He argues that gender labels among the Oyo-Yoruba are subject to performances and struggles through negotiation in the political sphere involving the leaders and the followers from "realms of ideological and social production. ${ }^{16 "}$ Thus, the organized hierarchy among men and women's relation is missing but is found between relationships between a husband and his wife. The elegun, who are males, are wives of the orishas and are therefore subordinate to them. Thus, in the literal sense, a wife is subordinate to her husband.

Identifying how women are excluded from the Oyo-Yoruba priesthood of Ogun and how females dominate the Sango priesthood, Matory suggests that there are binaries in the Yoruba performance of gender. He privileges the complementary roles in gender relations amongst the Yoruba by acknowledging that even though the wives of the kings hold the secondary position of power in the palace, they can also be potential threats to the throne by preferring their children to be the next in acceding to the throne to other

\footnotetext{
16 Matory, Lorand. (1994). Sex and the Empire that is No More: Gender and the Politics of Metaphor. Minneapolis: University of Minnesota Press p.3
} 
children in the polygamous household. ${ }^{17}$ In this way, Matory sheds light on why a Yoruba woman might not be sidestepped in the power structure. Women hold a significant position in it.

Matory also highlights the power that Yoruba women hold, as demonstrated by the narrative of the Oyo king, in which the mother of the king was killed upon his accession to the throne to prevent her from having an authority over the kingdom. ${ }^{18}$ Matory's work is significant here because he suggests that the male fears women's power because it reflects female possession of some forms of authority over the king. Conversely, Matory's work also brings out some of the potential flaws in the "complementarity argument" by claiming that the delegation of wives as palace officials was adopted in the nineteenth century when authority no longer privileged royalty. He attributes this development to the colonial intervention in the Oyo-Yoruba community.

Matory breaks away from the usual argument that appears to privilege the Yoruba woman as independent by pointing out how such embellishments of "queen" hide under the rhetoric of "wifeliness. ${ }^{19 "}$ Matory's emphasis on how "gigun" or "mounting" (from which "magun" "don't mount" is derived) signifies how the culture subverts women's freedom. Although Matory claims that Magun depicts patrilineal authorities, he fails to

\footnotetext{
${ }^{17}$ Matory, Lorand. (1994). Sex and the Empire that is No More: Gender and the Politics of Metaphor. Minneapolis: University of Minnesota Press p.11

${ }^{18}$ Matory, Lorand. (1994). Sex and the Empire that is No More: Gender and the Politics of Metaphor. Minneapolis: University of Minnesota Press p.139

${ }^{19}$ Matory, Lorand. (1994). Sex and the Empire that is No More: Gender and the Politics of Metaphor. Minneapolis: University of Minnesota Press p.24
} 
identify how such authorities are used to subjugate women for their sexualities. This current study's focus on sexual subjugation will help us to understand how power is approached from the male and female's perspective. This present study will bridge this gap by examining the ways that a woman's liberty is subverted in the Yoruba mythology. Nevertheless, Matory's work marks a significant contribution to the Yoruba gender studies by juxtaposing both Sango and Ogun and exploring their patriarchal authorities.

In "Gelede: Art and Female Power among the Yoruba," Henry and Margaret Drewal (1990) present a very interesting aspect of the Yoruba gender ideology which is often overlooked in gender discourses. Using the ethnographic observation in some parts of Yoruba community, the Drewals examine the communicative and cultural meanings of Gelede by looking into how women's powers are demonstrated through efe and gelede performances. These performances are spectacles that address social behavior in the Yoruba community. The authors identify how the Yoruba see women as purveyors of supernatural power akin to those possessed by Yoruba deities. The Drewals identify how Yoruba society accesses and reveres this power. They also demonstrate with illustrations how this power relates to the female genitalia. The authors cite with examples how the power of women can be both benevolent and malevolent. Looking into the aesthetic and symbolic meaning of Gelede, the Drewals evaluate women's social and spiritual roles in the Yoruba society. They identify the different masquerades in the Yoruba society and their peculiarities. The authors recognize and suggest that generalizations and speculations in this area might be misleading and that the different masquerades should be studied independently. The takeaway from Drewals' study is their presentation of how gelede is performed by men in honor of the mothers. 


\section{How Women Negotiate with Patriarchy in Yoruba Traditions}

Finally, this section examines the literature on the relationship between men and women in Yoruba society. Practices that appear to privilege women and those that appear to malign them are interpreted differently. While some debates focus on the effects of societal perceptions of women, others argue that women are a necessary part of the society from their positions in it. The different modes of interpreting the experience of women are at the center of literature on African women in the Yoruba oral genres. This section focuses on what has been written so far on how Yoruba oral genres reflect and/or offer models for being a woman in Yoruba society.

There is literature that offers windows into women's negotiation with patriarchy. Among such literature, is Gender Perception and Development in Africa: A SocioCultural Approach. In this work, Kolawole (1998) engages the different gender themes in Nigeria from an ethnocentric perspective. Kolawole argues that African women's experience cannot be fully engaged from historical records except by examining the mythologies and other oral traditions that point us to the authentic perception of women. She further states that doing this does not neglect the real-life experiences of women but points us to them.

Similarly, in "Women in the Yoruba Religious Sphere” Olajubu (2003) demonstrates how women occupy a central place in the religious worldview of the Yoruba people. The author shows how this understanding informs how both men and women engage in mutually beneficial roles in the Yoruba religious sphere. She also illuminates the tensions between the prominent roles of Yoruba women in religion and their perceived marginalization, emphasizing how Yoruba women have challenged 
marginalization in ways unprecedented in other world religions. She argues that women are the repository of the Yoruba indigenous tradition and have played prominent roles in its formation as well. Olajubu highlights how the various famous male deities like Oduduwa, could be females, a premise that a selected number of scholars of Yoruba origin support. The position is built on how men could have been identified with the prominent roles held by women.

Literature that offers insights into Yoruba ideas of how women negotiate with patriarchy is marginal. Such literature establishes women's struggle in the tradition that they find themselves. In City of 201 Gods: Ile Ife in Time, Space, and the Imagination, Olupona (2011) presents a scenario typifying such negotiation processes. Olupona argues that gender discourse in religion is significant in understanding sacrifices and redemptive suffering among the Yoruba. He demonstrates how a woman could be used as a negotiating tool in gaining access into the secrets of invaders. By analyzing how Moremi, a goddess in a Yoruba myth, engages the use of her sexuality to liberate her people from the hands of Igbo raiders, Olupona highlights how using her sexuality for that purpose deprived her of being reckoned as heroic among the people of Ile-Ife who would waive such expectation for men and also celebrate men's sexual prowess.

Conversely, in "Hidden Power: Osun, the Seventeenth Odu," Rowland Abiodun (2001) presents an overview of women's power in Ifa and similar genres. Abiodun connects one of the ways Osun identifies with Ori (inner head or destiny) by citing one of her oriki that celebrates the female adornment of the hair. Similar to Matory's explication of the travesties, Abiodun demonstrates how hair adornment is not limited to the female alone. The author establishes, with examples, a number of Yoruba chiefs who adorn their 
hair by plaiting it. The author also illustrates the power of Osun in an Odu that presents Esu (the deity of the crossroad) as the son of Osun. Abiodun suggests that the identification of Osun with the male deities could have been a result of her power and influence. Abiodun is clearly supportive of women's exploits. The author indicates how a particular Ifa verse shuns prolonged bachelorhood. He identifies that males' domination of the positions of authority today is not found in Yoruba oral traditions.

Abiodun also notes how women have monopoly over ase, the most powerful element in the Yoruba spiritual universe, and how they express their control over ase through their roles as aje and as mothers. Abiodun's observation corroborates Hallen (2000) and Love (2012) on the power of aje. Similarly, Abiodun shows how ase controls the physical plane and the measure of power that also accrues to Osun. He demonstrates how a number of antiquated materials in the Yoruba tradition preserved women's exploits in the materials. Abiodun suggests that this signifies how women had considerable status in antiquity. To Abiodun, the power of Osun - the epitome of the power attributed to ase is the same power as that of the aje. Abiodun interprets the danger associated with female deities, mothers, and women in general in Yoruba thinking as an expression of the society's sense of the female as the purveyor of orderliness. The author, however, fails to provide information about how females negotiate their access in trying to survive the culture in claiming the ase. Thus, this study extends the discussion started by Abiodun in bringing out how women exercise their power in ensuring order in the Yoruba society while negotiating their space and access to power. Yoruba gender ideology encompasses a wide range of ideas. While a number of scholars concentrate on the positive side, others privilege the negatives. As a point of departure, this study explores how Yoruba oral 
genres such as oriki (panegyric poems), owe (proverbs), and itan (myth) shed light on societal perceptions of the process of men and women's negotiations in a hegemony dominated by men. 


\section{Chapter III}

\section{DEFINITIONS OF TERMS}

\section{Texts and Contexts of the Yoruba Oral Traditions}

We can best understand Yoruba life, worldview, culture and tradition in their codified oral forms. This chapter introduces readers to the Yoruba oral genres that I will be using in the study. These genres are oriki (panegyric poetry), orin (songs), owe (proverbs), and itan (myth). One reason that explains the persistence of these oral forms and even the aura that surrounds them is the fact that the Yoruba privilege oral forms over the written. This is so because Yoruba considers the orality of words to be more authentic and powerful. Devotees of Ifa still believe that the power in the orality of Ifa is missing in the written text. This also explains why Yoruba people privilege the act of oath taking. There is power in the words that people utter when they take oaths. This Yoruba respectful attention to the spoken word resonates with Coward's (1988) argument in Sacred Word and Sacred Text. He argues that the oral words are more powerful than the written words in the world religions. Coward maintains that both the Jewish and the Christian scriptures have survived through stages of metamorphosis from oral to the written. He asserts, "Contrary to the modern tendency to think of 'scripture' in terms of printed books, we have seen that in all of the world religions the oral experience of scripture is at least as strong, and in some instances stronger, than the written." Similarly, Beier (1996), while referring to the authority accorded Yoruba myths asserts, "They are as valid as Genesis. ${ }^{20 "}$

${ }^{20}$ Beier, Ulli. (1996). The Origin of Life and Death: African Creation Myths. London, Ibadan Heinemann p.viii 
Some scholars have however, contested the authenticity of some of Yoruba oral genres. They argue that these may not be uniquely Yoruba. For example, Law (1984) observes how Samuel Johnson's Yoruba historical records were influenced by Christian tradition from Johnson's adoption of some terms such as the representation of Christian attributes of God to Yoruba Olodumare. While Law points out that historian of African religion could have been rationalizing events and rendering "euphemisms, instead of belated discovery of alternative renditions," the varying strands of orality is a feature of the tradition. The many varying traditions affirm or validate any oral tradition as diverse. Oriki, Owe, and Itan present nuanced meanings.

\section{Oriki (Panegyric poetry)}

Oriki is derived from two words, ORI and KI. Ori literally means a head. It is also a reference to destiny. The head is the bearer of a person's destiny in Yoruba worldview. $\mathrm{Ki}$ means to praise. In other words, in a loose translation, oriki means to praise the head or destiny. In the Yoruba culture, oriki is any form of praise or eulogy for people, places, things, or animals. Amongst all these, oriki for humans and sacred beings is given the most respectful attention in the Yoruba culture. Oriki can also function as a serenade for sacred beings or the Orisa. As praise words, Oriki can be a marker of identity that details a person's place of origin, family history, and his or her great deeds. The Yoruba derives great esteem from an oriki performance. Oriki defies easy classification because of its multiple forms such as music/song, chants, names, poems, etc (Aaron, 2018). A poetic rendition of Ijala in story form can be regarded as an oriki.

In "I Could Speak Until Tomorrow: Oriki, Women and the Past in a Yoruba Town," Barber (1991) describes oriki as a "master discourse." As a master discourse, 
Oriki wraps around every Yoruba lifestyle. Barber explores the essence of oriki among the Okuku people of Oyo Yoruba. Barber (1991) defines Oriki as a "genre of Yoruba oral poetry that could be described as attributions or appellations: collections of epithets, pithy or elaborated which are addressed to a subject. ${ }^{21}$ " Barber is careful to note that because the Yoruba is a diverse community the style of Oriki varies from one community to the other. The determining element in this variety is the purpose of the oriki.

Similarly, in "Praise Poems as Historical Data: The Example of the Yoruba Oríkì," Awe (1991), provides a general definition of Oriki as "a salute, or poetic citation, which is publicly recited. ${ }^{22 "}$ Awe identifies three classifications of Oriki, namely; oriki ilu, oriki onile, and oriki inagije. Oriki ilu are praise poems for towns. An Oriki ilu, for instance, will praise a town such as Ibadan this way: "Ibadan Omo ajoro sun. Omo a je Igbin yoo fi ikarahun fo ri mu. Ibadan maja-maja bii tojo kin-in-ni, eyi too ja aladuugbo gbogbo logun, Ibadan kii ba ni s'ore ai mu ni lo s'ogun." This Oriki means that:

Ibadan likes a certain fruit called Oro and people from Ibadan can feed on Oro in their sleep. Ibadan would eat a snail and use its shell to for pap meal. Ibadan do not wage war-Ibadan will wage war with their neighbors. Ibadan

\footnotetext{
${ }^{21}$ Barber, Karin. (1991). Barber, Karin. I could Speak Until Tomorrow: oriki, women and the Past in a Yoruba Town. Edinburgh: Edinburgh University Press for the International African Institute p.7

${ }^{22}$ Awe, Bolanle. (1974). Praise Poems as Historical Data: The Example of the Yoruba Oríkì. Africa: Journal of the International African Institute, 44(4), 331-349. Retrieved from http://www.jstor.org.ezproxy.fiu.edu/stable/1159054
} 
does not make friend with people without going to war with them. ${ }^{23}$

The Oriki Ibadan above are recited for Ibadan indigenes. Yoruba people render Oriki onile for patrilineal lineages. The Oriki for the Adebisi lineage (my great father) for instance, reads as follows:

Adebisi omo Idiikan, Omo Ogboja

Omo baba Gbadegesin, Olonje ni Ogun abiku

Baba Sariyu ti n se tapa tapa; ase malu tese tese

Ani karabadan wa jeun, Adebisi baba Gbadegesin

Eni dele Adebisi ti o yo, esin lo so monu re be

Olonje ni ogun abiku, baba Sariyu

Abi keran bi isu elu, omo ogboja.

Translation:

Adebisi of Idiikan, the child of Ogboja

The child of baba Gbadegesin, whose food can cure an abiku

Sariyu's father, who kills the cow with his bare legs.

He'll invite the Ibadan people to a feast, Adebisi, Gbadegesin's father;

${ }^{23}$ My translation. 
A person who visits Adebisi's house and is not satisfied is shameless

A person with food will cure the children born to die.

The beef meal that he shares are as large as yam tubers, the child of Ogboja. ${ }^{24}$

The Oriki idile above is recited for those born into the family that owns the oriki. The oriki for the Adebisi lineage shows how generous is Adebisi, the child of Ogboja. In addition, the characteristics of the progenitor are the constituents of the praise poem for the descendants. This praises act as triggers as they will in no doubt elicit acts of generosity from any one from the lineage to hear them. They are models "of" and "for" the Adebisi "brand."

The Yoruba recite the oriki inagije, which represents an individual praise poem, for individuals. Just like inagije, Oriki idile (oriki for patriliny) can also function as an individual poem. In the Yoruba context, people recite a single oriki for individuals' achievements or great exploits. Wealthy people receive more praises or oriki because of their statuses in Yoruba societies. The wealthy, by responding with money gifts for the reciters, demonstrate their acceptance of such acclaims. Oriki are also of economic value to reciters during ceremonial gathering such as weddings, burials, and other celebrations, because they can be paid for recitations.

While the rendition of Oriki is generally interpretive, writers like Awe (1974) and Barber (1991) suggest that relying on this, as the only data source is incomplete. By this, both authors mean that we should examine other genres such as proverbs, poems, and

\footnotetext{
${ }^{24}$ This is my lineage oriki and the translation is mine.
} 
myth in tandem to arrive at their better interpretations, rather than limiting research data to one source. This suggestion confirms that the study of any oral tradition should not be restricted to just one genre because the more data genres we collect, the better the outcome.

Because this study focuses on the female, women's oriki will feature prominently. We will focus our reflections mostly on Ekun Iyawo, (bridal lamentation) a type of oriki. These are oral renditions verbally expressed at weddings. Brides chant Ekun Iyawo, as an oriki, or a bridal lamentation on the eve or on the day of the wedding ceremony.

The literature that examines Ekun Iyawo is rather scanty. In "Documenting Social and Ideological Change through Yoruba Oriki: A Stylistic Analysis” Barber (1981) identifies the difficulty in paying the bride price and attributes this to its high cost. While the specific setting of her study informs Barber's submission, it would be inaccurate to say that the Yoruba regards the bride price ritual as part of a trading economy. Rather, paying and receiving bride price are symbolic ways in which the groom and bride's family demonstrate their support of, and their agreement with the marriage. An underlying Yoruba sense here is that what one does not invest in does not carry any value. The Yoruba sees this negotiation as involving a giving away rather than the sale of their brides. As Oriki, ekun iyawo, which women champion, perform these Yoruba ideas about brides, grooms and the symbolisms of marriages. Women's negotiation of patriarchy is aptly demonstrated in oriki. 


\section{Owe (Proverb)}

Owe is another genre in Yoruba oral traditions. The word "Owe" translates as "proverb." Owe are clusters of words or ideas that are woven together. This means that they are complex sayings with deeper meanings that must be unraveled. Oyelade (1999) refers to Yoruba proverbs as "cultural markers. ${ }^{25 "}$ Y Yoruba proverbs economize words because they say so much with so little. The Yoruba use proverbs as prescriptions or guidance in difficult situations. They are brief words that offer so much detail about the consciousness and history of the people.

Owe also carries other captivating meanings; it is a vehicle through which difficult subjects are relayed. A popular Yoruba proverb says, "Owe le sin oro. Oro lesin owe. Bi oro ba sonu, owe laa fi n wa." This proverb translates as "Proverbs are horses (vehicles) of speech and vice versa. In the absence or the loss for a word, the Yoruba employ proverbs to search it out" (my translation). A similar explanation is found in the book entitled "From Conceptual Metaphors to Cultural Metaphors: Metaphorical Language in Yoruba Proverbs and Praise Poems." Ehineni (2017) examines the roles that metaphor plays in proverbs. Ehineni argues that rather than a general meaning, proverbs have specific meanings, which are peculiar to the culture and community from which they emerge. Ehineni suggests that we should study Yoruba proverbs and metaphors together. In Yoruba, there is really no distinction between proverbial and metaphorical sayings.

\footnotetext{
${ }^{25}$ Raji-Oyelade, A. (1999). Postproverbials in Yoruba Culture: A Playful Blasphemy. Research in African Literatures, 30(1), 74-82. Retrieved from http://www.jstor.org.ezproxy.fiu.edu/stable/3820474 p.74
} 
In “A Socio-Cultural Study of Negative Portrayals of Masculinity in the Yorùbá Oral Literature: Yorùbá Proverbs as a Case Study," Agbaje (2016) discusses some Yoruba proverbial sayings that present Yoruba masculinity in an unflattering light. They reflect a Yoruba cultural critique of masculinity. Similarly, Owomoyela (1988) did a comprehensive study of Yoruba proverbs, identifying rhetoric as one significant element of Yoruba proverbs. Owomoyela also explores a selection of Yoruba proverbs, showing how they reflect a strong sense of gender neutrality in Yoruba thinking. Although the author apologizes for adopting the masculine descriptions of some of the words, this study questions why the adoption of the masculine description of certain words is normalized. Owomoyela examines the prescriptive and the proscriptive proverbs. Essentially, these are the major functions of the proverbs in the Yoruba tradition. Both function as tools for guiding individual's decision-making. These set of proverbs are always in the form of the statement, "We don't do this ... to avoid this ..." For instance, the statement, "Akii ba eni gbe, ka ma moju e" means "We don't live with a person and say that we are unfamiliar with such a person.” This proverb suggests that people should learn how to live harmoniously. Another example is "Bi ko ba nidi, obinrin kii je kumolu." This loosely translates as. "Without a reason, a woman does not bear the name, Kumolu." This study will pay particular attention to the functions of proverbs that focus on women in the chapters that follow.

\section{Gelede}

Gelede is a masquerade that combines aesthetics with ritual performances in the Yoruba culture. Topics of Gelede usually range from womanhood, childhood, and sexuality, to social harmony. Although the focus of Gelede is not limited to these, this 
study focuses on themes that relate to how men and women access power in the performance of Gelede. The Drewals (1983) examine different performances of the Gelede at Ilaro. Lawal (1996), in an effort to bridge the gap in Drewals' study, examines Gelede from the emic perspective. This study considers the gaps in both Drewals and Lawal by paying attention to how women navigate patriarchy in Gelede.

\section{Itan (Yoruba Mythology)}

Unlike the Gelede performances, which enact social situations in ritual and aesthetics, Yoruba mythology is a collection of stories of superhuman endeavors. Specifically, Yoruba cosmological myths are selections of sacred and aesthetic stories about the creation of the world from the Yoruba viewpoint. These stories feature the exploits of the gods and goddesses and legendary beings. They also offer insights into the Yoruba understandings of how aspects of the Yoruba culture, such as practices and events, originated.

Cosmological myths are found in Ifa, a system of divination. Ifa is also personified as a divinity. There are debates on the inconsistencies in the representation of Ifa as an oracle, as well as a divinity. Clarke (1939) highlights these discrepancies in his study of Ifa in Illorin, pointing out the differences in the representation of Ifa either among scholars who referred to Ifa as a deity or as an oracle. Clark favors the work of Epega (1995) and Johnson (1921) who both refer to Ifa as "the great consulting oracle," and Lijadu (1901) who also refers to Ifa as "the words of Orunmila." Bascom (1991) confirms that Ifa is both Orunmila and a system of divination. Olupona (1993) presents the possible cause of the discrepancies, asserting that the missionaries who were also scholars of Yoruba religion were influenced by their missionary purpose in presenting 
their understanding of Ifa. However, Matory (2005) in "Black Atlantic Religion:

Tradition, Transnationalism, and Matriarchy in the Afro-Brazilian Candomble" observes, "Yoruba Christian writers advance a project of documentation and codification that have been easily appropriated by literate nationalists on both sides of the Atlantic, in projects validating the Yoruba national legacy. . ${ }^{26 "}$. The slight distinction in the representation of Ifa among scholars results from their different backgrounds. Christian scholars and the devotees of Ifa are coming from different ideological perspectives. Their rendition of Ifa divination text would be influenced by their religious interpretations.

The Yoruba see the natural world as being governed by the divine. Similarly, Lawal (1996) states that "Yoruba associate artistic creativity with the divine" (p. xvi). While writers like Courlander (1973) render secular versions of these myths, others privilege genres that Orisa devotees hold dear to their heart in their sacred form. The rendition from Trieber (1974) preserves a recent or redacted version of the myths. Works circulating on Yoruba sacred myth have received a great deal of attention among pioneering scholars of African religion such as Parinder (1967), Bascom (1969), Wande Abimbola (1975, 1977), Olupona (1993, 2011), Epega (1995), and Pembertom III (2000).

\section{Ijala}

Other myths that this study will briefly examine are found in Ijala. Ijala are either oriki or stories about hunters, and they are dedicated to the lineage of Ogun, who is affiliated with iron. A source of Ijala that this study adopts is "Content and Form of

\footnotetext{
${ }^{26}$ Matory, James Lorand. (2005). Black Atlantic Religion: Tradition, Transnationalism, and Matriarchy in the Afro-Brazilian Candomblé. Princeton, N.J: Princeton University Press p.94-95
} 
Yoruba Ijala" by Babalola (1966) and Oladipo (1963). It is likely that the reason scholars are not engaging with Ijala from the female perspective is that they believe that hunting is strictly for men. Because this study examines how women are conceptualized in the context of a hegemony controlled by men, Ijala is another good source to consult. This choice is not informed by Ijala's hyper-masculine nature but rather Ijala's emphasis on hunting as an exclusively male domain. In addition, despite the male-centeredness of Ijala poetry, few of the records speak about the relationship between men and women. It would seem that Ijala is a more recent genre because of its records of incidents centering on the Alaafin of Oyo, and the subtle silence of Ijala about women directs us towards understanding how gender is performed among the Yoruba.

While Ijala details the lives of men's exploit as hunters, Oyewumi casts doubts on the representation of men as the warriors and not women. Oyewumi questions how the sexes of the character are detected since Yoruba language is not gendered. Other genres like the Oriki and Owe are pithy statements that economize words, saying much with little, and Itan tells a story in detail. Indeed, the many renditions of the same account point to the richness and the diversity of the Yoruba oral tradition. Because of the mutability of the oral text, some of its renditions are malleable. As will been seen in chapter three, the names of the performers change in some cases and their situation remains the same. The point of convergence in all the genre types is that they are markers of the Yoruba identity. These markers will be useful for teasing out gendered ideologies in the Yoruba culture.

Yoruba oral traditions are collections of the Yoruba life that detail how the Yoruba organize themselves. Owe, Oriki, Gelede, Ijala and Itan hold their different 
spaces in the Yoruba tradition. Despite their divergent genres, they depict similar ideas in their different rhetorical contexts. In some cases, they act as a guide for how one must live or conduct oneself in societies. In other cases, they act as a repertoire of knowledge. As observed by Awe, taking a linear approach to study these genres independently, rather than collectively, is insufficient. Indeed, limiting an ideological study of gender relations in oral traditions to just one critical approach is inadequate. Moreover, for the purpose of this study, which is to explore and reconstruct how the Yoruba performs gender, it is very important that the different genres be considered together to arrive at a productive result. 


\section{CHAPTER IV}

\section{GENDER IDEOLOGIES AS EXPRESSED THROUGH YORUBA MYTHOLOGY.}

\section{Introduction}

Through the analyses of a selection of Yoruba myths, this chapter argues that women's resistance to power is occasioned by men's entitlements grounded in the Yoruba patriarchy.

\section{Obatala and the aje}

By examining the tales of Yoruba deities, we can understand something about power relations between men and women in Yoruba society. As mentioned in the literature review, in the Yoruba worldview, aje are super intelligent beings. Hallen (2000), describes aje as a type of human personality. In most cases, women represent this group of people. Obotunde Ijimere (1966) presents the poetic adaptation of the play of Obatala in The Imprisonment of Obatala. Obatala is one of the Orisa. He is identified with whiteness or purity. He is also known by other names, such as Orisha Nla (High divinity) or Olufon. In the Yoruba creation myth, Obatala is responsible for the creation of lands over the seas. He is also known as Orisanla—-the supreme deity's son.

In one of the adaptations of the Yoruba mythologies, Beier (1980) presents Obatala as the deity presented with the task of molding people from clay. He often needs water to actualize his tasks. However, during a famine, Obatala is unable to find water to complete his work of molding people. He seeks water to no avail. In his search, he 
eventually finds the witches' well, and takes as much water as he needs without paying due regard to the witches.

The witches are angry and decide to punish Obatala. He outwits them by planning with Orunmila to rescue him. Once the witches reach for Obatala at Orunmila's house, where he is now hiding, they are asked to stay back to be treated with a little hospitality. The witches refuse, stressing that they come for Obatala. The witches ordered Orunmila to fetch Obatala for them. Orunmila is insistent that they stay, and they eventually agree to eat. Unknown to the witches, Orunmila casts a spell that glued them to their seats. By the time the witches discover the deception, their power has become impotent. They beg Orunmila to release them. Orunmila asks them to promise that they will not wrong Obatala once they are released. The witches agree not to harm Obatala or his family. After Orunmila releases the aje, Obatala gives him his iron bell, which, according to Beier, enables devotees of Ifa to sound bells in the night whenever they are on the way to make sacrifices.

In this myth, women control the power. Even when the aje are glued and are left "powerless," their powerlessness is also an instance of power because Orunmila still needs to negotiate for Obatala's freedom. That Orunmila has to negotiate for Obatala's freedom suggests that both male gods recognize the power that the women hold. This moment of negotiation also represents a moment of survival for Obatala because he is unable to gain freedom without Orunmila playing pranks on the aje. Since Orunmila could not achieve Obatala's freedom by peaceful communication devoid of tricks, his action suggests that in the absence of communication in a gendered structure, a number of men resort to domination. 
It is intriguing to note that Orunmila, who represents a peaceful deity in the Yoruba tradition, would engage in acts of deception. As noted by Micheal Kaufman (2007) in "The Triad of Men's Violence," “[t]he formation of an ego on an edifice of surplus repression and surplus aggression is the building of a precarious structure of internalized violence." Kaufman argues that masculinity is beyond the "sum total of an oppressive form of behavior" because it is embedded in the structure that nurtures the male ego. Orunmila can be seen nurturing Obatala's ego by not allowing Obatala to take responsibility for his action; he also recognizes that without manipulating the aje, he is powerless. In this way, the power that both Orunmila and Obatala held in stifling the aje's freedom is really no power at all, but a depiction of the male entitlement through deception leading to domination. This literary power play also manifests in public life. The condition of women's negotiation with patriarchy comes with a cost.

As identified in “Contextualizing Men's Violence: The Personal Meets the Political,” Kimmel (2007), identifies differing perspectives on violence, both at the social and individual level. Paying attention to the different reactions toward how men and women experience masculinity, Kimmel argues that individual men feel powerless, whereas the targets of masculinity (the women) experience a form of domination. ${ }^{27}$ The aje experience domination by being forced to let go of Obatala against their will. Kimmel highlights capital violence and how violence itself is shaped and tied to the economic conditions of those who enact it. Kimmel stresses an understanding of the male "entitlement" as the focal point to address the stereotypical understanding of masculinity

\footnotetext{
${ }^{27}$ Kimmel, Michael. (2007). “Contextualizing Men's Violence: The Personal Meets the Political.” Edited by Laura L. O'Toole, Jessica R. Schiffman, and Margie L. Kiter Edwards, in Gender Violence: Interdisciplinary Perspectives. New York: New York University Press p99
} 
rather than to address power itself. Even though "capitalism" is a contemporary phenomenon, we identify how survival compels both Orunmila and Obatala to use their domineering power in negotiating with the women. The enactment of domination on the aje signifies that in protecting the men, in acts of negotiation with women, deception is often employed.

\section{Moremi}

Moremi is an epic heroine from Ile-Ife who has been deified as a goddess. Moremi's historic exploits, which the city commemorates in Edi festival, is observed annually. In "Moremi: An Epic of Heroism," Abiri (1976) presents a play featuring Moremi. During an intrusion into Ile-Ife, Moremi seeks the counsel of an Ifa priest to ascertain the cause of Ife raiders. Moremi's quest is to understand how to avert further damages that the raiders bring to Ife. In the play, Moremi is imprisoned after the Igbo raiders capture her. At the courtyard of the Igbo city, she spends a long time working hard for the Igbo king. The King's wives notice her unique ways of getting her work done and deduce that she may be a threat to their polygamous relationship with the King. The King also notices how Moremi's presence and charm affect his court, and he orders Moremi to be brought to him. The King loves her immediately and asks her to marry him. Abiri's version of the epic of Moremi details that jealousy and strife of the co-wives carry subtle gendered meanings. The version by Abiri vividly portrays how women can perpetuate patriarchy.

In another version by Olupona (2011), Moremi is a very elegant woman who is married with a child, Olurogbo. Moremi first marries King Oranmiyan of Ife when Igbo armies (not the contemporary Igbo of South-Eastern Nigeria) attack her people. The Ife 
Igbo raids bring economic calamity to the Yoruba. Seeing that indigenous Ile-Ife men will rather avoid the situation of addressing the raiders themselves because they envision these raiders to be non-humans, Moremi takes it upon herself to investigate the nature of these raiders and capture them. Moremi's act of initiation suggests that she is no ordinary woman. Before embarking on her journey, Moremi seeks the help of Esinmirin, the sacred spirit of the river who told Moremi to discover the secret power of the Igbo. Esinmirin warns Moremi that the subterfuge will cost a dreadful sacrifice. However, courageous Moremi agrees to do it. She promises the river deity that once her exploit to unravel the mystery of the Igbo raider is successful, she will give the river a great gift of any choice. Thus, she allows herself to be captured as part of the spoils of war. Subsequently, Igbo warriors again raid Ife communities. When the King of Igbo spies the beautiful captive, he takes an immediate interest and commands her to be his wife. As Queen, she becomes intimately familiar with the Igbo way of life, even asking her new husband the secret of Igbo success in battle. The King tells her that the secret is hidden in their bamboo fiber costume. Once the costume is exposed to fire, it explodes. Now, having the Igbo secret at her fingertips, Moremi escapes to her husband, King Oranmiyan. The Ife are liberated from the oppressive Igbo raiders. After the victory, River Goddess Esinmirin requires Moremi to fulfill her promises by sacrificing her only child, Olurogbo to the sacred river. Fully aware of the consequences that go with noncompliance - paying even more dearly, Moremi obliges the River spirit's request.

Moremi's acts of courage, sacrificing her sexuality and her son to liberate her people, represent an act of negotiation. Olupona (2011) asserts that while Ife continues to celebrate her deeds, the myth derides Moremi as a seducer because her heroism is 
depicted because of her sexual prowess, which is linked to her vagina. ${ }^{28}$ As identified by Olupona, Yoruba blends the attributes of women and men; Moremi's deed resembles that of a warrior hero. This blending of attributes could account for one of the reasons that scholars of Yoruba consider the Yoruba gender relation as androgynous.

The irony in Moremi's story is that men's occasion of sexual prowess is not identified as a weakness, rather it is laudatory. This position aptly corroborates Butler's explanation of Simone de Beauvoir who claims that one is not born a woman. Indeed, as explained by Butler in "Performative Acts and Gender Constitution: An Essay in Phenomenology and Feminist Theory," (1988) "gender is in no way a stable identity or a locus of agency from which various acts proceed; rather it is an identity tenuously constituted in time - an identity instituted through a stylized repetition of acts. ${ }^{29 \text { " }}$ That men have overtime been identified with some acts does not justify that such acts are stamped in their DNA. Instead, the switching of roles is an indication that gender identity can be constituted differently.

\section{Yemoja}

Similarly, Yemoja presents another account that celebrates womanhood in both Africa and the diaspora. In Orisha: The Gods of Yorubaland, Gleason (1971) likens Yemoja to womanhood. Gleason portrays Yemoja as the mother of the Orisha. It is from

\footnotetext{
${ }^{28}$ Olupona, Jacob. (2011). City of 201 Gods: Ile Ife in Time, Space, and the Imagination. Berkeley \& Los Angeles: University of California Press p.208

${ }^{29}$ Butler, Judith. (1988). Performative Acts and Gender Constitution: An Essay in Phenomenology and Feminist Theory. Theatre Journal, 40(4), 519-531. doi:10.2307/3207893 p.519-531
} 
Yemoja that the stream flows through other seas. Similar to Gleason's portrayal, Teresa N. Washington (2013) presents a personified attribute of Yemoja--"Yemoja is the lifeblood that flows through the Atlantic; the ocean that receives the soul of the captives. ${ }^{30}$ "

Among the many renditions of the tales of Yemoja, her relationship with Obatala seems to be one of the themes that address how women bargain with patriarchy. Yemoja is from two words, "iye," which means mother and "omo-eja", the child of a fish. Yemoja is also acclaimed as the ancestral mother of the Gelede mask and the fruits the mothers produce, which are children, and she is also the power of aje (Otero \& Falola, 2013: p.xix). Otero \& Falola present different representations of Yemoja in both Africa and the Diaspora.

The present study on Yemoja explores the myth of Yemoja and its gendered ideologies among the Yoruba. Reckoned as one of the River goddesses, Yemoja's experience of patriarchy is significant because it presents male and female relationships as found in the Yoruba culture. For this purpose, this study examines the myth of Yemoja from Beier. ${ }^{31}$
"Yemanja (Yemoja) was a woman of great beauty. But she
had only one breast. Because of this, she did not want to marry, because she feared that her husband might ridicule

\footnotetext{
${ }^{30}$ Otero, Solimar. \& Falola, Toyin. (2013). Yemoja: Gender, Sexuality, and Creativity in the Latina/o and Afro-Atlantic Diasporas. Albany: State University of New York Press, 2013 p.216-218

${ }^{31}$ (my corrections on Beier's rendition are included in brackets).
} 
her and expose her secrets to the world. One day she was walking home sadly from the market and she said to herself: 'how sad it is to be lonely; to return to a childless house; to have no husband to cook for.' Ogun overheard what she said because he was walking along the same road. He felt a strong desire to marry her and seized her and said: 'Do not be afraid. I know I look fierce and all the world fears me. But I will do you no harm. I will look after you and protect you; but there is one thing you must promise: you must never make fun of my bloodshot eyes.' Yemanja agreed to marry him. She confessed that she had only one breast and she said" "You must promise me one thing, never touch my breast.' For a long time, they kept each other's promise. Yemanja bore many children to Ogun. One day Ogun wanted to please Yemanja and went to the kitchen to cook soup for her. But being unused to a woman's work, he dropped the pot, broke it and he spilled the food all over the floor. Yemanja, who had been resting, woke up at the noise. She rushed into the kitchen, and she did not realize how the accident happened she cried angrily: 'What are you doing in my kitchen! You with your bloodshot eyes!' Ogun could not control himself when he heard this. He struck her and she fell to the ground. But he 
felt sorry for her and he knelt beside her and stroked her breast. At this Yemanja began to tremble. She turned into water and slipped through his fingers. Ogun was sad to lose his wife. But then he said to himself: 'Gentleness is not for me! And he left the house to go out and fight many more wars, as he used to do. ${ }^{32}$

This tale vividly depicts that both partners made choices. The negotiation that takes place between the two of them supports this assertion. For Yemoja, there is no turning back; once Ogun violates her conditions, she turns to water. The situation of their relationships is according to Matory (1994) a portrayal of power. Matory asserts, "Ogun's relations with wives are clumsy." ${ }^{33}$ Ogun fails to recognize the complementary distinctness of the wifely role. Indeed, when he tries to fill that role, he destroys the primary icon of both the kitchen and the altar of gods that "mount" - the pot." However, this present study argues that there is no evidence that signifies that cooking is the primary role of a wife in this tale. There is a subtle gender role when Yemoja anticipates having a husband so that she can fulfill certain roles like cooking.

Perhaps, if culinary activities were interpreted as Yemoja's passion, and not "gender roles" per se, attention can be taken off the roles and the focus would be on the choices. Here, rather than see Ogun's failure in the kitchen as a clumsy display of macho

\footnotetext{
${ }^{32}$ Beier, Ulli. (1980). Yoruba Myths. Illustrated by Georgina Beier. Cambridge; New York: Cambridge University Press p.45-46

${ }^{33}$ Matory, Lorand. (1994). Sex and the Empire that is No More: Gender and the Politics of Metaphor. Minneapolis: University of Minnesota Press p.18
} 
power, his disposition could be interpreted as a weakness. Perhaps, Matory assumes a "role" for Ogun and Yemoja. Ogun's display of "power" by hitting Yemoja suggests Ogun's sense of entitlement. Kimmel (2007) suggests that we understand an "entitlement" as the focal point to address masculinity rather than power itself. ${ }^{34} \mathrm{His}$ argument is that the displacement of men's entitlement results in violence. Thus, Yemoja's accusation of Ogun evokes violence from Ogun, rather than a conversation. Rather than appease Yemoja, Ogun chooses to excuse himself via "lovemaking." Nevertheless, as depicted in the myth, Ogun and Yemoja's negotiation suggests power on the male side and displays a sense of entitlement.

\section{Osun}

Osun's tale is also similar to Yemoja. According to Ogungbile (2001), the Yoruba claim that the sixteen-cowrie divination is Osun's possession. That Osun is connected to the sixteen cowrie's divination suggests that she is a powerful being whose power is not informed by gender roles. ${ }^{35}$ For, if this was so, no woman will be able to function as a diviner. Osun is the leader of the aje (Ogungbile, 2001). With these characteristics, it is

\footnotetext{
${ }^{34}$ Kimmel, Michael. (2007). “Contextualizing Men's Violence: The Personal Meets the Political.” Edited by Laura L. O'Toole, Jessica R. Schiffman, and Margie L. Kiter Edwards, in Gender Violence: Interdisciplinary Perspectives. New York: New York University Press p.109

${ }^{35}$ Abiodun, Rowland. (2001). Hidden Power: Osun, the Seventeenth Odu. Edited by Murphy, J. M., \& Sanford, M.-M. (2001). Osun Across the Waters: A Yoruba Goddess in Africa and the Americas. Bloomington: Indiana University Press. Retrieved from http://ezproxy.fiu.edu/login?url=http://search.ebscohost.com/login.aspx?direct=true \&db=nlebk\&AN=6658 $\underline{1 \& \text { site }=\text { ehost-live \&scope }=\text { site }}$ p.189-191
} 
no wonder that Osun's ability to control, and, or manipulate her power in relation to the world, portrays the Yoruba cosmology as non-gendered. Osun is the goddess of cool water and the only female amongst the sixteen deities at creation. She is annually celebrated in the Osun/Osogbo festival. Badejo (1996) maintains that:
African ethnolinguistic cultures were, and are, upheld by the presence of institutionalized structures such as her myriad cultural festivals, her extensive oral literary corpora, and her quintessential socio-political practices, all of which are thoroughly interwoven throughout the philosophy and fabric of African living. ${ }^{36}$

Situating the festival drama as a context for the historical and cultural knowledge imparted during Osun festivals, Deidre brings to fore the significance of this deity to the Yoruba culture. Joseph Murphy and Mei-MeiSanford (2001) cite Osun as "the renewing source of life." When a woman or a man is barren, Osun is sought after. Not only is she a source, but she is also "an empire builder" in the words of Awe, and "she heals with cool water and destroys life in the raging flood. ${ }^{37 "}$ Abiodun (2001) considers Osun as the most powerful female Orisa. Diedre refers to OseTura, an Odu Ifa (1996) that details the

\footnotetext{
${ }^{36}$ Badejo, Diedre. Osun Seegesi. (1996). The Elegant Deity of Wealth, Power, and Femininity. Trenton, N.J: Africa World Press p.xv

${ }^{37}$ Abiodun, Rowland. (2001). Hidden Power: Osun, the Seventeenth Odu. Edited by Murphy, J. M., \& Sanford, M.-M. (2001). Osun Across the Waters: A Yoruba Goddess in Africa and the Americas. Bloomington: Indiana University Press. Retrieved from http://ezproxy.fiu.edu/login?url=http://search.ebscohost.com/login.aspx?direct=true \&db=nlebk\&AN=6658 $\underline{1 \& \text { site }=\text { ehost-live \&scope }=\text { site }}$ p.6-7
} 
proceeding account of Osun. However, the detail of Osun and creation by Diedre is not included in the version of Ose Tura divination preserved by Epega (1995). This study, thus, relies on Badejo's (1996) record:

When Olodumare sent all the IrunMole to come to organize the world, Ogun, Sango, Orunmila, Obatala, and all other deities, Osun was the only woman among them. They came down to arrange everything; they put everything down in order. When they assembled, when they had their meetings, they did not invite Osun. Being an aje, Osun destroyed their plans. They were not successful with any of their program. They had to return back to Olodumare. They reported everything and Olodumare asked them, How about Osun? They said that because she is a woman, they did not invite her to their meeting. Olodumare asked them to go back and beg Osun. So all the IrunMole came back. They apologize and they made a sacrifice to Osun. And Osun said that she wanted all the initiation of ritual they perform for men which they used to keep women behind, she wanted it. And she wanted every woman who is powerful like her to be initiated. So they called Osun, and they showed her everything. ${ }^{38}$

\footnotetext{
${ }^{38}$ Badejo, Diedre. Osun Seegesi. (1996). The Elegant Deity of Wealth, Power, and Femininity. Trenton, N.J: Africa World Press p.73
} 
Osun's liberation of women shows that long before the "Western" Feminist agenda for equality, she was already fighting for the equal status of women. In another version, Osun engages intimately with Obatala, Sango, \& Esu. Perhaps, Osun is more than one deity or personality, for men are at liberty to sexually engage with multiple partners in the Yoruba culture. Osun is also one of the possessing goddesses (Matory, 1994). There is another rendition by Courlander (1973):

Osun, a very beautiful woman is interested in learning the art of divination. She approaches Obatala to help her. However, Obatala is not going to teach her despite his attraction to her. One day Obatala goes to the river to bathe. After he is done bathing, he reaches out for his white garment, but he can't find it. Esu, the deity of the crossroad and a trickster figure already reaches out for Obatala's garment before Obatala finishes with his bath. Obatala cannot afford to walk naked to the town because it is not befitting for him to do so. It is in this state that Osun comes around and sees how Obatala panics. Osun asks Obatala to promise to teach her the art of divination, again, and this time she will help find Esu and get him his white garment. Obatala agrees. Osun goes in search of Esu, finds him, and asks him to return the garment. Esu says on one condition, she has to get intimate with him. Knowing that there is no other way to get Obatala's garment from Esu, Osun agrees. 
After this encounter, Osun returns to Obatala with his garment and Osun learns the art of divination. ${ }^{39}$

In both tales, while both Courlander (1973) and Badejo (1996) highlights the significant power of Osun and the autonomy that both she and her female followers command, attention is shifted from the resistance that Osun endured in getting her power. This study tries to show that such autonomy that women hold does not come without resistance. This tale is a good example of an act of negotiation and the cost of meeting its demands. Osun, an ambitious woman, will go to any length to attain her dreams, but to do this, she must negotiate even in an uncomfortable situation.

Osun's negotiation signifies the options the goddesses or women in particular are presented with; the rules of the "games" as creatively coined by Kandiyoti. This is the rule of the games that the goddesses contend with. Sheffield's (2007) stance on masculinity explains the scenario between Osun and Esu. In her Sexual Terrorism, Sheffield submits, "Under patriarchy, men are entitled to sex; it is a primary vehicle by which they establish and signal their masculinity. From the male perspective, female sexuality is a commodity, something they must take, dominate or own." This stance is vividly reflected in the sexual encounter between the deity, Esu, and the goddess, Osun, which corroborates Kandiyoti's (2013) argument that “different manifestations of

\footnotetext{
${ }^{39}$ Courlander, Harold. (1973). Tales of Yoruba Gods and Heroes. Greenwich, Conn: Fawcett Publications p.78
} 
patriarchy present women with distinct "rules of the game" ... in the face of oppression. ${ }^{40 "}$ This aptly captures the theme in this study.

I chose the myths above others because they aptly demonstrated how women negotiate with patriarchy. From the analyses of these myth we see that the various conditions that some of the female deities operate in, while navigating the patriarchal system to attain or express their power, do not come without their resistance. In most cases, they negotiate with the patriarchal system for their right, space, and access to resources. The conditions that the goddesses and the female characters are presented with is different from those of the males. While the males are entitled to their positions, women are positioned as resisting with acts of negotiation.

${ }^{40}$ Kandiyoti, Deniz. (2013). Bargaining with Patriarchy. Edited by McCANN, Carole. \& Kim, Seung-Kyung in Feminist Theory Reader: Local and Global Perspectives. New York \& London: Routledge p.274 


\section{CHAPTER V}

\section{PROVERBS AS SOURCES OF YORUBA GENDER NOTIONS}

\section{Introduction}

As one of the tools of communication among the Yoruba, proverbs are given respectful attention. The respect that the Yoruba accord proverbs speaks largely to their recognition of nature and human experience as repositories of knowledge. This is because the raw materials from which the Yoruba create proverbs are natural events and human experiences. Proverbs then are replete with moral lessons gleaned from nature and human experience that do not only reflect Yoruba insights into gendered realities but also, guidelines on how to perform gender. This chapter will focus on proverbs with a view to shedding light on often-neglected gender discourses they offer in the Yoruba tradition. I will explain how these proverbs are used in the culture and what their textual meanings represent in a broader context.

\section{Section 1. Common Yoruba Gendered proverbs}

Proverb 1: “Orisa je'n pe meji obirin kan ko si”

Translation: "The deity that would see two women joyfully share a husband is nowhere to be found."

Usage: Nobody wants to be rivaled.

Explanation: Although polygamy is an integral part of the Yoruba tradition, the Yoruba understand that women are loathed to share their husbands with other women. In some cases, the "love," attention for their husbands, and jealousy cause co-wives to harm one 
another. Similar to most cultures, this prevailing Yoruba practice has no room for role reversal, in that a woman cannot marry multiple husbands-she will be regarded a prostitute. Nevertheless, this proverb also speaks to a male situation. While patriarchy seems to "favor" men, it demands outrageous conformity from them. In patriarchy, the man must perform, that is, act out being a man. Marrying multiple women is a way of performing masculinity. But this means that men prove their manliness at the expense of the freedom and preferences of women. In negotiating with patriarchy, women use expressions of jealousy and disputes that are typical of polygamous households to contest this situation. The proverb thus speaks to the subtle and sometimes covert ways in which women protest expressions of patriarchy. The "Orisa je'n pe meji obirin kan ko si" proverb is evoked during disputes between a husband and his wives, as a commentary on why such disputes happen—no woman/human being would like to have a rival. In other words, it is a truism of polygamy that co-wives share husbands with reluctance, and that many women will express their discontent in the face of this form of patriarchal imposition.

Proverb 2: "Obinrin siwa wu, o lohun o lori oko"

Translation: "When a woman misbehaves, she will claim that she lacks the luck (head stands in the place of luck which can also be read as someone who is not destined to marry) of a husband."

Usage: This proverb is evoked when someone's failure results from negligence. There is an assumption that such person is predestined for failure. 
Explanation: A woman without manners or character will remain unmarried. In this proverb, the underlying assumption is that a woman who is married has a good character or is lucky while one who is unmarried is not. This suggests one of the reasons why women accommodate or contend with the excessive demands of patriarchy and remain married to their husbands - they do not want to be thought of as lacking in good moral character. This proverb is also rendered for people without a good or moral character to explain their misfortunes. Although the usage provides less information about how women negotiate in the patriarchal system, the text suggests one of the ways that women can prove their moral character in negotiating with patriarchal demands. This text also provides a context for understanding why a woman would readily accept to be married into a polygamous relationship rather than be perceived as lacking in character.

Proverb 3: "Pasan ta fi na ya'le, ou'n be laja fun 'yawo"

Translation: "The whip used for lashing the first wife is kept on the rooftop for the junior wife."

Usage: One could avert the bad luck that happened to one's superior by learning from the superior's experience.

Explanation: The same way the first wife was punished for misbehaving, punishment awaits the second wife for similar behaviors. Although this proverb means that one could avert the bad luck that happened to one's superior by learning from the superior's experience, it reveals an underlying Yoruba sexist understanding that equates women with children. The sense here is that children are not the only people punished through flogging with canes. Also, women are expected to understand that not only is polygamy a 
normal part of the culture but that it is also a context in which the husband is entitled to beat his wives. Contrary to Oyewumi's (1997) argument that the Yoruba is not organized by gender, sex hierarchy is organized. Yoruba culture does not frown on men who punish their wives through flogging with canes if they can offer justifications for doing so. In most cases, no one dares to question a man who flogs his wife/wives. Oyewumi might argue here that wife beating is not intrinsic to Yoruba culture, and that it was introduced into the Yoruba tradition through the colonial project. However, there is nothing to indicate to us that wife beating was not already a Yoruba practice before the Western mediation into the Yoruba land. Despite Sheffield's (2007) assertion that "laws and public attitude of wife abuse have slowly been evolving, ${ }^{41}$ " there is yet to be laws that consider wife beating as violent in Nigeria. The Nigerian legislation, the penal code, under section 55 (d), clearly considers wife beating as the legal right of a husband married by the customary law. While the husband can beat his wife, there is no law in Nigeria that gives the liberty to women to beat their husbands in return. This study does not advocate for responding violence with violence. It suggests, however, that women are considered to be more culpable of breaking the law by beating their husbands than men are if they flog their wives. This proverb provides a window into the unequal power that exists between Yoruba men and women.

Proverb 4: "Esin obinrin soro gun, o le gbeni subu"

Translation: "Just like a horse, women are hard to ride. It can lead to one's fall."

\footnotetext{
${ }^{41}$ Sheffield, Carole. (2007). Sexual Terrorism. Edited by Laura L. O'Toole, Jessica R. Schiffman, and Margie L. Kiter Edwards, in Gender Violence: Interdisciplinary Perspectives. New York: New York University Press p.117
} 
Usage: It is used to advise people to be careful in making decisions.

Explanation: This proverb suggests that women can contribute to the downfall of their husbands. Proverbs like this one are rendered in situations where a husband is about to make a crucial decision and is in need of good counsel. He is advised not to trust his wife but to use his discretion, for his wife may lead him (the husband) astray through her bad counsel. There is an underlying negative cultural disposition towards women expressed through this proverb. This suggests that women are unreliable; thereby, men should discount their counsel. This disposition can model how a wife behaves towards a husband. The cost of being a reliable wife is that she may go out of her way in doings things to earn the respect and trust of her husband. In some cases, this may involve the woman preparing good meals to draw her husband closer to her. It can also provoke complicity on the women's part (especially in a polygamous setting).

Proverb 5: "Bi ko ba nidi obirin ki'i je Kumolu":

Translation: "Without a reason, a woman does not bear the name Kumolu."

Usage: This proverb is used to explain that there is no effect without a cause.

Explanation: Kumolu is a name given to men. In a situation where a family is unable to produce a male child, the female child, known as Kumolu, takes on the male child's position and prerogatives. For this reason, a woman is not offered a leadership position. This text suggests that gender roles have always informed the Yoruba hierarchy. While this proverb serves to place men in leadership positions, it places so much burden on men. The only condition on which a woman would be allowed to take on a leadership role is the absence of a male child. In negotiating with patriarchy, women must compete 
with the absence of a male successor, which in some cases subject their family to polygamy in the search of a male successor.

Proverb 6: "Iya ni wura, baba ni jigi."

Translation: "Mothers are gold; fathers are mirrors."

Usage: This proverb is used for praising parents.

Explanation: Mothers are indispensable while fathers are reflections. It is possible to argue that the Yoruba equates women with a material thing, gold, which can be lost, but to do this is also to say that mirrors can break. In other words, gold and mirrors embody different characteristics in children's lives. Gold beautifies while the mirror reflects the gold. Thus, this proverb is directing us to the complementary roles of women and men. This suggests that Yoruba proverbs can also seek to balance the understanding of women and men by making them no less or more to each other. The negotiation of patriarchy may involve bringing together the qualities that favor complementarity.

Proverb 7: "Ọmọ t'ó jọ baba, ló bo àșírí ìyá ẹ̀."

Translation: "The child that resembles his father is a vindication of his/her mother."

Usage: This is a testimony that the wife is a faithful woman.

Explanation: In the past, there was no mechanism for checking the DNA of a newborn baby. Parents depended on the external indicators of facial resemblance to determine whether the child born was legitimate, especially if the circumstances of the pregnancy raised questions. In situations where the legitimacy of the child was indeterminate, the public considered it to be a bastard. The child's mother then become the bearer of that 
shame. Thus, this proverb offers a vindication for women faced with the question of the legitimacy of their newly born children. It would be impossible to ascertain who to truly hold responsible for childlessness due to the lack of resources and access to information. Investigating how society handles a situation where all the wives of an impotent man are unable to conceive begs the question of the intelligence of women in the face of survival. In order to avert the shame of a man's impotence, wives, motivated by the quest to hide their husband's impotence might surreptitiously beget bastard children by having extramarital affairs. Giving birth to bastard children to protect the husband from societal shame is one of the strategies women employ to boost societal perceptions of a husband's virility. Wives feel compelled to cover up for an impotent man. Their silence may not only be reinforced by traditional decorum but may also reflect an acceptance of their matrimonial situations.

Section 2. (The following proverbs and their translations are from the collections of Owomoyela (1988).

Proverb 8: "Akii fi ojojumo ri oko eni; omo eni ki i ni obakan. ${ }^{42}$ "

Translation: “A woman does not see her husband every day; one’s child never has a half-brother."

Usage: The proverb is intended to advise against having unachievable expectations.

Explanation: Owomoyela defines "obakan" as a half-brother. The proverb means that a woman should not expect to engage intimately with her husband every day. Since obakan

${ }^{42}$ Owomoyela, Oyekan. (1988). A Kì í; Yorùbá Proscriptive and Prescriptive Proverbs. Lanham, MD: University Press of America p.37 
directs us to polygamy, it signifies that men can engage with whichever wife pleases them. This proverb points to the fact that a woman in a polygamous house engages in an unachievable expectation should she expect her husband to engage intimately with her every day. However, it is not an undue expectation of her husband to engage as he likes. The sexual relationships between women and men are unbalanced. A husband functioning within polygamy does not have to engage in undue sexual expectation because of his wives' competitiveness. However, his wives would be expecting too much by thinking that either of them can have him to herself every day.

Proverb 9: "A ki i moo ko omo ka tu n' mo ale ee. ${ }^{43}$ "

Translation: One does not recognize a daughter's suitor and yet tolerate her illicit lover.

Usage: This proverb is used for sanctioning honesty in human relationships.

Explanation: This proverb explains that a woman cannot go out with two men at a time. Once she introduces a man to her family that man will be recognized as her partner. Violating that rule means that she is crossing the line of dignity and honesty. A man, on the other hand, does not have to abide by the same rule. Thus, women must maintain loyalty to one man but learn to cope with their husbands' disloyalty.

Proverb 10. From Olajubu (2003).

“K'okunrin r'ejo k'obinrin pa'a.”

Translation: "A man sees a snake, but a woman kills it. ${ }^{44}$,

\footnotetext{
${ }^{43}$ Owomoyela, Oyekan. (1988). A Kì í; Yorùbá Proscriptive and Prescriptive Proverbs. Lanham, MD: University Press of America p.65

${ }^{44}$ Olajubu, Oyeronke. (2003). Women in the Yoruba Religious Sphere. USA: State University of New York Press p.40
} 
Usage: This speaks to the support that men and women can render to each other.

Explanation: This proverb explains the complementary roles of women and men in Yoruba society.

\section{Conclusion:}

The proverbs presented and interpreted in this chapter are vehicles through which meanings are conveyed. While symbolically the proverbs are indicative of something else, their non-symbolic textual appearance also performs a symbolic function: they point us to how the Yoruba's organization of their hierarchy, which is both genderless and gendered in outlook, is structured. Unlike the myth, which provides information on how women find spaces within the males dominated hegemony to control power despite their subordinate statuses, the proverbs provide a context for situating women's subservience in the patriarchal culture. Women's roles and behaviors are clearly defined in the proverbs. Men could function as the head in a polygamous family, but women could only function as the subordinate. The defined roles of men and women embodied in the proverbs are gendered expectations sanctioned through time in the Yoruba culture. A proverb that praises women for being subservient is different from one that praises a woman for her courage. Scholars of Yoruba are reluctant to document some of the proverbs that disparage women to avoid misinterpretation of the Yoruba culture. Indeed, while collecting proverbs to be analyzed in this study, I found that the proverbs that disparage women are much more than those that praise them. Women's disparagement in these proverbs suggests that patriarchy is intrinsic in the Yoruba culture and it is codified in the form of proverbs. To avoid subjecting the reading of these proverbs to misinterpretation, this study focused on the selection of a handful of the proverbs that 
disparage women for comparative analysis. I chose those proverbs because they are the popular Yoruba proverbs that Yoruba people use on a regular basis. 


\section{CHAPTER VI}

\section{NEGOTIATING WITH PATRIARCHY: ORIKI AS WINDOWS INTO GENDER IDEOLOGIES AMONG THE YORUBA}

Bridal lamentations, rara or ekun iyawo, are a rich source of the Oriki genre that details women's performance of gender in the Yoruba culture. This chapter interprets ekun iyawo (brides' lamentation/tears) and iwa (an Ifa text), sacred Yoruba oral renditions verbally expressed at weddings and religious consultations, respectively. This chapter also interprets Ijala, an oriki specifically targeted at male hunters, as well as Gelede, a mask performance for women.

\section{Ekun Iyawo}

Marriage represents a very important institution among the Yoruba of Nigeria. The occasion of marriage represents an accepted time when the bride, who must be a virgin becomes intimate with a man, her husband, for the first time. Ekun literally translates as "tears," and iyawo, literally translates as "wife." Ekun iyawo then means "the bride's tears." Shedding tears is one of the ways to express emotions in times of pain or joy. In a sense, Ekun iyawo is a form of bridal shower during which the bride publicly announces her departure from her parents' home to be married to a man. In most cases, and traditionally, the wedding day is the day that the bride would be meeting the groom for the very first time. Marriage is a relationship that the parents of the bride and the groom negotiate on behalf of their offspring. Alarina (an intermediary) communicates on 
behalf of both the bride and the groom before their wedding. This signifies that the bride does not have much say in choosing the man to marry.

The Oyo Yoruba is renowned for ekun iyawo. While this bride ritual takes place, in most cases, on the eve of the wedding ceremony, some brides perform ekun iyawo on the wedding day. This occasion of ekun iyawo offers an opportunity for reflecting on some of the virtues that the bride had gleaned under the tutelage of her parents. It also offers an opportunity for the bride to show respect to her parents and those who are witnessing the occasion, and to demonstrate that the family she is leaving behind means so much to her. Ekun iyawo is still practiced amongst the Yoruba but might be more prevalent in the prehistoric period. For a bride, getting married marks the disconnection from those that she grew up with and those she might not have the opportunity to see again. It is a phase of her life where the bride moves into the unknown - a new family she barely has any relationship with.

In “Ękuń Ìyàwó: Bridal Tears in Marriage Rites of Passage among the ÒyóYorùbá of Nigeria," Jacob Olupona and Sola Ajibade (2005) argue that ekun iyawo is an avenue for the bride to express her bittersweet emotions by weeping during her marriage ceremony. ${ }^{45}$ This is a time of reflection. It marks a sorrowful day for the parents of the bride because once the ekun iyawo is chanted by the bride, the time to leave her parents' house occurs in just few hours. Olupona and Ajibade assert that the performance of ekun

\footnotetext{
${ }^{45}$ Olúpònà, J., \& Ajíbádé, Ş. (2005). Ękuń İyàwó: Bridal Tears in Marriage Rites of Passage among the Òyó-Yorùbá of Nigeria. In Patton K. \& Hawley J. (Eds.), Holy Tears: Weeping in the Religious Imagination (pp. 165). Princeton; Oxford: Princeton University Press. Retrieved from http://www.jstor.org.ezproxy.fiu.edu/stable/j.ctv36zq11.13 Accessed on 11/19/2018 p.165
} 
iyawo is paradoxical because of the mixed emotions of joy and sadness that follow it. The crux of the ceremony is when the bride receives the blessing of her parents, which is usually marked by emotional outpours from both the parents and the bride. In most of the ekun iyawo, the chant requires that the bride weep bitterly. In many cases, this form of tears is catching, especially among the well-wishers.

\section{Oral Rendition of Ekun Iyawo}

The lamentations are always in the form of a tête-à-tête; the bride chants and the parents bless her in return. This section examines the selections of chants in this regard. The beginning of the chant follows:

Baba oko ti n’ o baa,

Koun ma seleninii mi

Iya oko ti n o baa

Koun ma seleninii mi.

Orogun ti n o baa

Koun ma seleninii mi.

Ire ani ki n' ma fabiku sewo

Ire ani ki n ma rin niso agan
My prospective father-in-law

May you not denigrate me;

My prospective mother-in-law;

May you not belittle me.

The co-wife that I am about to meet;

May she not malign me.

Bless me that I may not give birth to

children predestined to die

Bless me that I may not be barren

The two chants above are pregnant with meaning. In the first chant, the bride expresses her anxiety about moving. The content of her anxiety signifies her imagination of what an indigenous marriage is about and it also suggests that the Yoruba culture 
celebrates polygamy. This chant reflects that the style of living among the Yoruba is communal with her husband and his parents, and the wife that the bride would be joining as a co-wife. In the case where there is no co-wife, the bride who is to be the first wife expresses her anxiety about the groom's mother and the rest of the family that she's joining as a subordinate. The oriki clearly demonstrates that Yoruba are organized by seniority as well as gender hierarchy. Here, the gender hierarchy is synonymous with what Patricia Collins (2000) in "Gender, Black Feminism and Black Political Economy" refers to as a form of family rhetoric and practices that shape differences in how male and female access resources. ${ }^{46}$ In this case, the resources are power. For the bride to be lamenting suggests a sort of male elevation that suppresses the female power. There is an imbalance here; there is no groom's lamentation. Ekun iyawo offers a window into Yoruba ideologies of gender relations and it is an avenue for a bride to display her virtues and value of virginity. While virginity is generally celebrated in the Yoruba culture as a commendable virtue, only the females and not males are obligated to be virgins. The chants that support this is the one recorded by Dejo Faniyi (1975):

"Odo kan, odo kan,

Ani ti n be laarin igbe, Araa 'waju o gbodo mu

Ero eyin o gbodo bu we.

"A secret river That flows in the jungle, Those who walk in front dare not drink out of it, Those who walk behind dare not bathe in it.

\footnotetext{
${ }^{46}$ Collins, Patricia. (2000). Gender, Black Feminism, and Black Political Economy. The Annals of the American Academy of Political and Social Science, 568, 41-53. Retrieved from http://www.jstor.org.ezproxy.fiu.edu/stable/1049471 Accessed on 12/3/2018. P.41-53
} 
Emi Ayoka debe, mob u boju

Ojuu mi waa doju oge,

Idii mi wa didi ileke o

Ileke ani te e na ka ti o pe

E legbe mo ni,
I, Ayoka, came here and wash my face.

At once, I change to a lovely virgin.

My waist is full of lovely beads

Count the beads, oh dear friends, if any is missing,

Stripe me naked ${ }^{47}$

In the version of the bridal lamentation presented by Barber (p.114), the words, "strip naked," are missing. In the version by Olupona and Ajibade, the bride also states that if she is not found to be a virgin on her wedding night, she should be stripped naked publicly. ${ }^{48}$ The groom, however, is not required to abide by the rule of virginity. This patriarchal disparity shuts women out of a marital balance and continues to enforce inequalities among the sexes. Ekun iyawo therefore suggests a situation of pleasure and pain - the subservience on the women's part is most often overlooked. Attention is paid mostly to the new status of dignity that is linked to being married.

${ }^{47}$ Abimbola, Wande. (1975). Yoruba Oral Tradition: Selections from the Papers Presented at the Seminar on Yoruba Oral Tradition, Poetry in Music, Dance and Drama. Yoruba Oral Tradition: Selections from the Papers Presented at the Seminar on Yoruba Oral Tradition, Poetry in Music, Dance and Drama. Nigeria: Dept. of African Languages and Literatures, University of Ifẹ p.

${ }^{48}$ Olúpònà, J., \& Ajíbádé, Ş. (2005). Ękuń İyàwó: Bridal Tears in Marriage Rites of Passage among the Òyó-Yorùbá of Nigeria. In Patton K. \& Hawley J. (Eds.), Holy Tears: Weeping in the Religious Imagination (pp. 165). Princeton; Oxford: Princeton University Press. Retrieved from http://www.jstor.org.ezproxy.fiu.edu/stable/j.ctv36zq11.13 Accessed on 11/19/2018 p.168 


\section{Negotiating with Patriarchy}

Deniz Kandiyoti's (2013) notion of the patriarchal bargain, which refers to the strategies that women adopt within a set of concrete constraints, also offers a crucial theoretical lead in this study. Kandiyoti argues that different manifestations of patriarchy present women with distinct "rules of the game" and call for a range of different strategies to "maximize security and optimize life options with varying potential for active or passive resistance in the face of oppression. ${ }^{49}$ Kandiyoti asserts that the power of the patriarchal bargains in contributing to women's subservience also shapes how they interact within these constraints. In an attempt to maximize security and life options, women become implicit participants in a system that celebrates male domination. In the examples provided by Kandiyoti, women are presented as helpless people who have to depend on their husbands for survival. These women operate under the domination of their husbands; this means that their husbands who are heads of the families control their wives' labor. In the absence of the rewards of their labors, women resist. Kandiyoti maintains that the number of the women who resisted while bargaining with patriarchy remain in the system because of the security they hope to find.

Just as Kandiyoti claims, women's life cycle in the "patriarchally extended family" is such that the denial and the struggles that they endured when they were newly married will be replicated when they become mothers-in-law. By then, they will be in control and have authority over their own daughters' in-laws. In this way, this patriarchy is cyclical for women because of the internalization of some of the practices

\footnotetext{
${ }^{49}$ Kandiyoti, Deniz. (2013). Bargaining with Patriarchy. Edited by McCANN, Carole. \& Kim, Seung-Kyung in Feminist Theory Reader: Local and Global Perspectives. New York \& London: Routledge p.274
} 
in surviving the patriarchal society. In this ekun iyawo, the bride reflects on her new status, which comes with fears of contending with the subordination looming around her enjoyment's day. The implication of women's bargaining in the patriarchal system is that the system leaves women exploitable. In addition, as argued by Kandiyoti, the breakdown of the system means that women will have no power over their daughters' in-laws. The consequence is the same for their husbands.

In "Multiculturalism and the Promise of Happiness," Sara Ahmed (2007) demonstrates how the "happy housewife" is a fantasy figure who erases signs of labor under the guise of happiness. Ahmed identifies how this happiness is paradoxical and shaped by social belief-simply put, it is what is necessary for survival. The author traces how societies locate happiness in marriage for women ${ }^{50}$. Even though ekun iyawo has its cultural values for women, some of the aspects of this bride's lamentation reinforce the stereotypical notion of masculinity. Ekun iyawo positions the bride as comfortable with her potential role; however, she must oblige to the calling to go to her husband's house because the choice is not hers to make. The bride's tears illustrate the fear of her new position - the lowest in the order of classification in her new family. That the bride must contend with her new family demonstrates a system that places men at the center of happiness in which women have to strive for in connection with marriage. Ahmed mentions the connection of this projection to what Friedmann terms as "the public fantasy of happiness." In becoming a happy housewife, the woman is obligated to labor in tasks

\footnotetext{
${ }^{50}$ Ahmed, Sara. (2007). Multiculturalism and the Promise of Happiness. New Formations P.121-123
} 
which she has to fulfill. ${ }^{51}$ Olajubu (2003) asserts that while the bride is in her natal background, she commands an access to power, but "in her marital agbo-ile, the bride is in theory a dependent in status and identity, with little or no power. ${ }^{52}$ " Similarly, Olupona and Ajibade (2005) also affirm that the bride's lament is a portrayal of the perceived low status ascribed to brides. ${ }^{53}$

Kandiyoti (2013) maintains that the autonomy that brides strive to accede to from the senior women in the household is cyclical. ${ }^{54}$ The longer the bride stays the more power she has. Eventually, a new wife will replace her position, beginning the cycle again. Kandiyoti maintains that from this cycle, women perpetuate this form of patriarchy. This suggests that even though women are at the mercy of the tradition's oppression, they end up reproducing it. From the ekun iyawo, we see how marriage reinforces the fear of being barren for the bride. This fear offers a motivation for having children "Bless me that I may not give birth to children predestined to die young" for with children comes the new wife's transition from the lowest state in her husband's

\footnotetext{
${ }^{51}$ Ahmed, Sara. (2007). Multiculturalism and the Promise of Happiness. New Formations P.121-123

52 Olajubu, Oyeronke. (2003). Women in the Yoruba Religious Sphere. USA: State University of New York Press p.31
}

\footnotetext{
${ }^{53}$ Olúpònà, J., \& Ajíbádé, Ş. (2005). Ękuń İyàwó: Bridal Tears in Marriage Rites of Passage among the Òyó-Yorùbá of Nigeria. In Patton K. \& Hawley J. (Eds.), Holy Tears: Weeping in the Religious Imagination (pp. 165). Princeton; Oxford: Princeton University Press. Retrieved from http://www.jstor.org.ezproxy.fiu.edu/stable/j.ctv36zq11.13 Accessed on 11/19/2018 p.168

${ }^{54}$ Kandiyoti, Deniz. (2013). Bargaining with Patriarchy. Edited by McCANN, Carole. \& Kim, Seung-Kyung in Feminist Theory Reader: Local and Global Perspectives. New York \& London: Routledge p.101
} 
family, to being in the position of authority over her children. Thus, producing offspring can be a tool of survival, or a bargaining chip so to speak. The bride needs to bear a child, and most importantly a male child, to continue to secure herself in the marriage until her old age. Without children, she would continue to be maligned by her husband's family or her society. A woman who loses her child is respected more than a woman who never had any. Having children as a tool to gain power suggests that in the perpetuation of patriarchy, women are active participants as well as legitimizers.

\section{Iwa}

Iwa is literally defined as a behavior or code of conduct. According to Abimbola (1975), a Yoruba form of ethics or moral character, iwa should not be confused with the Western ethical system (1975). In most cases, it represents either a right or wrong character. It can also stand as a default characteristic without qualification of good or bad. In this case, a person with iwa has a good character while a person without iwa has a bad character. Ifa divination presents iwa as a woman and a code of conduct. I will interchangeably use iwa as both moral character and as a person. This study interprets a version of Ifa text on iwa that mentions iwa as the first wife of Orunmila who is one of the divinities of Olodumare (God). This section presents iwa in Odu Ifa as presented by Abimbola (1975) in Yoruba. Translation is mine:

$\underline{\text { Iwa Yoruba Version }}$

Lo difa fun orunmila

\section{$\underline{\text { Iwa English Translation }}$}

Ifa divination was performed for 
Baba n lo gbewa niyawo

Nigba ti Orunmila yoo kooko gbeyawo,

Iwa lo gbe niyawo.

Iwa si ree

Suuru lo bii

Nigba ti Orunmila fee gbe Iwa niyawo,

Iwa ni, ko buru,

Oun o fee o.

Sugbon kini kan ni o

Eniyan ki i le oun jade o

Eniyan ki i lo oun nilo omi ojo

Eniyan ki i fiyaa je oun ...

Orunmila ni, Haa Olorun maa je

Oun a toju e

Oun o kee o,

Oun o ge o

Lo bag be Iwa niyawo
When father was about getting married to

Iwa,

When Orunmila was to first marry his

wife,

He wedded Iwa.

And this Iwa,

Was Suuru's (patience) child.

When Orunmila was about to wed Iwa,

Iwa said, there was no problem.

She would marry him

But it was on one exception,

Nobody divorces her.

. Nobody wastes her like the rain water.

Nobody mistreats her.

Orunmila exclaimed, Haa God forbid!

He would take care of her;

He would cherish her;

He would adore her;

That's how he wedded Iwa. 
Igba to gbe Iwa niyawo

Igba to pe titiiti

Lo ba suu ...

Lo ba bere sii da iwa laamu

Bo gbe e

A ni ko gbe e re

Bo so o

A ni ko so o o re

Nigba iwa ri i pe wahala naaa papoju,

Ni iwa b ani ko buru.

Oun a lo silee baba oun.

Akobi Olodumare si ni babaa re naa,

Suuru, baba iwa.

Lo ba digba

Lo ba ko jade nile

"Lo ba gbode orun lo.
When he wedded Iwa, After a very long time,

He got tired.

He began to provoke Iwa.

If Iwa held something,

He would say that she didn't hold it well.

If she said something,

He would say she didn't say it well.

When the problem was beyond Iwa's ability,

Iwa was fed up. She said that it was no trouble at all.

She would leave for her father's house.

The first born of Olodumare (God) is Iwa's father.

Suuru (patience) is the father of Iwa/character.

Then she packed her things, Then she moved out, Then she went to heaven. ${ }^{55}$

${ }^{55}$ Abiodun, Rowland. (2001). Hidden Power: Osun, the Seventeenth Odu. Edited by Murphy, J. M., \& Sanford, M.-M. (2001). Osun Across the Waters: A Yoruba Goddess in Africa and the Americas. 
From the rendition of iwa above, Orunmila falls in love with his heartthrob, Iwa, and marries her based on her terms and condition not to mistreat Iwa. But before he marries her, he must win her to himself with suuru (patience) by singing love songs for her and making promises not to desert her. However, after both Iwa and Orunmila are married for a while, Orunnmila is tired of Iwa and starts to mistreat her, going against his promises to her. When Orunmila will not abide by Iwa's terms and conditions, Iwa is frustrated and is forced to flee from her husband. Orunmila, unable to cope with Iwa's absence, decides to search for her. He goes to so many places in search of Iwa but he cannot find her. He then decides to offer sacrifices through divination to inquire where she was. After many attempts, he is able to win Esu (a god) who eventually brings Orunmila's case to Iwa in heaven. Iwa listens intently to what Orunmila has to say. However, she refuses to return with him to the earth. She promises Orunmila that she will always abide with him.

Iwa conveys two surface meanings: a denotation of character and a personification of a woman. In the first few lines, we notice a marital negotiation between a man and a woman who love each other. This stage of their relationship marks the beginning, when both parties are without the knowledge of what makes them irritable to each other. An examination of Iwa's attitude to her husband, as presented in the odu Ifa is different from the attitude of the bride's lamentation in ekun iyawo. Iwa is presented as a

Bloomington: Indiana University Press. Retrieved from http://ezproxy.fiu.edu/login?url=http://search.ebscohost.com/login.aspx?direct=true\&db=nlebk\&AN=6658 $1 \&$ site=ehost-live \&scope=site p.389-420 
condescending woman who knows what she wants and will not be compelled to submit to a convention.

The gender binary inherent in Yoruba ideology is depicted by the female subservience in ekun iyawo and the condescension in iwa. Unlike in the ekun iyawo, iwa shifts the focus of marital obligation from woman to man. There is a common Yoruba saying that "Suuru la fi n' soko obinrin." This translates as "Patience is required to be a husband to a woman." Iwa could be supporting this Yoruba adage. In this way, a man who is able to peacefully live with his wife would signify a man of character in the Yoruba imagination. Here the balance in the negotiation tilts in favor of both men and women. The man must have character, and patience. From lines 30 to 35, Orunmila is seen complaining. A woman can be accused of a lack of character if she complains. Orunmila complains about the situation he cannot reconcile. Unlike in ekun iyawo, which presents the woman as lamenting, instead of complaining, Orunmila's disposition could signify power in the face of resistance. A woman's lamentation signifies subservience. In contrast, a woman's complaints signify a lack of character. This implies that in the negotiation of patriarchy, men are at more liberty to express themselves.

In lines 40-95, Orunmila searches for Iwa to the best of his ability, depicting the difficulty of regaining a lost character. The Yoruba believes that when a person loses his character, he must give a lot to get it back. In some cases, he loses his character forever. For instance, Orunmila is forced to share Iwa with Olojo.

Abimbola presents Iwa as a very beautiful woman without a good character (1977:389-418). Orunmila falls in love with Iwa after he experiences failed marriages 
with other female divinities and marries her. However, after being married for a while, Orunmila is tired of Iwa and divorces her. He soon realizes that he cannot exist without her and decides to search for her. His neighbors are not happy with his decision and he loses favor with them. However, Orunmila decides to find her anyway. He searches for her at the house of the sixteen divinities to no avail. He later finds Olojo, who is now married to Iwa and who refuses to give Iwa back to Orunmila. After a series of fights and arguments, Orunmila snatches his former wife and takes her home.

According to Abimbola, women in Iwa symbolize benevolence and wickedness. A good character in the Yoruba worldview determines whether a man will have a fruitful or unfruitful life - children, wealth, health, etc. Indeed, as seen in the text presented by Abimbola, a man's possession belongs to someone else if he lacks Iwa because his lack of a good character will cause him to squander his wealth as Orunmila did when he lost Iwa, his wife, to Olojo. Unlike the women, however, having Iwa is not synonymous with survival for men. When Orunmila lost Iwa to Olojo, he was not lamenting. This suggests that women and men negotiate with patriarchy differently.

From lines 95-120, not included above, Orunmila pays dearly for his negligence in efforts to get Iwa back to him. Rather than trust herself to Orunmila and follow him back to earth from heaven where Iwa absconded to, she would rather be with her father, Suuru (patience). Patience symbolizes the epitome of character or a good virtue. Leaving her husband, who fails to meet her terms and conditions, signifies Iwa's audaciousness. Since Ifa is understood to be as old as creation itself, ekun iyawo could have come later. Perhaps, this could justify why Iwa's non-subservience and condescension support 
Oyewumi’s (1997) claim that social organization according to sexual biology was "invented" into the Yoruba tradition. ${ }^{56}$ For as indicated in Iwa, the eponymous character exudes a sense of independence which is not predetermined by gender inequality. However, rather than dismiss the ideology of gender in the Yoruba tradition, this study suggests that gender should be examined in the context of seniority as well as other characteristics that point us to how women and men access power in the Yoruba tradition.

\section{Ijala}

Ijala is a collection of hunters and blacksmiths' exploits. It is usually rendered for Ogun because of Ogun's affiliation with iron, and to hunters because they make use of machetes during hunting. Unlike the Oriki for an individual or a family, an Ijala is not motivated by an economic reason. During the festival of Ogun, or when hunters are having their meetings, Ijala is employed to recant great hunters' deeds during their lifetimes. Hunters also adopt Ijala to contest with each other, and whoever wins the contest is praised. Ijala chanting itself originates from Ogun who was a great hunter. According to Babalola (1964), Ogun commands his children before he dies, to pass on Ijala chanting to the next generation. ${ }^{57}$ In another legend, Ijala chanting began when Ogun defeated Aparo, who had denied him access to palm wine. On killing Aparo, Ogun commands his men that anyone who wishes to put him in a good mood must chant his

\footnotetext{
${ }^{56}$ Oyěwùmí, Oyèrónké (1997). The Invention of Women: Making an African Sense of Western Gender Discourses. London: University of Minnesota Press p.5

57 Babalola, S. A. (1964). The Characteristic Features of Outer form of Yoruba Ijala Chants. Odu, 1, 33-44. Retrieved on https://www.worldcat.org/title/characteristic-features-of-outer-form-of-yoruba-ijalachants/oclc/37462455\&referer=brief results p.4
} 
oriki of Ijala. Yemitan (1963) maintains that the origin of Ijala continued in this form until people started to monetize it. This section will examine Ijala in order to understand gendered ideologies in the Yoruba tradition. Specifically, this section will explore the hunters' stories below. Translations of “Omowonmi Wo’le Ni Ile-Ife,” by Yemitan (1963) are mine.

Omowonmi Wo'le Ni Ile-Ife

Ojo ko tojo, ojo ko tojo

Ode kan to sode sode

To fi'binu wole n'Ile-Ife n'joun;

Obinrin lodale, obinrin leke:

Obinrin lo se iku pa Omowonmi

To fi binu wole ni Ife

O so fun iyawo re pe ogun t'on se yi

Ko gbodo fi owo osi gbe onje

Fun on, Omo'mi titi aiye

Omo'mi se ode lo titi

\section{Omowonmi was Swallowed by the}

\section{Ground.}

Time is fleeting, time is fleeting

A hunter hunted, and hunted

This led him to angrily enter the ground in Ile-Ife;

A woman is a betrayal; a woman is unreliable

A woman led Omowonmi to his death This led him to angrily enter the ground in Ife

He told his wife that because of the herbal medicine he just prepared, She must not serve his food with her left hand

For him, Omowonmi, until eternity

Omowonmi hunted for a long while 
O se ode de Ile-Ife

L'o ba won nibiti nwon

Nwon pejo nwon mbo Ogun lowo

Omo'mi papa na ko obi

Oni ki won ba on fi bo Ogun

Lati fi dupe abo igbe-ode

Nwon ni onje ti tan ni le

Nitori o ti pe ki o to de

Nwon fun iyawore ni eko

Pe ki o fo o fun Omo'mi, oko re

Obinrin Omo'mi fo ‘e ko tan

L'o fi owo osi gbe eko f'oko re
His hunting took him to Ile-Ife

He met the hunters where they were all

gathered

Where they worshipped Ogun at that

moment

Omowonmi also gathered his obi

(kolanuts)

They should help him to venerate Ogun

with them.

Thanking Ogun for the safety of hunting in the forest

They informed him that there was no more left-over food at home

Because of his (Omowonmi's) lateness

His wife was given a pap meal

That she should give it to her husband

When Omowonmi's woman finished

preparing the pap meal

She used her left hand to serve her

husband the pap meal 
“Ha!” t'oko se, lo ba wo'le ni Ife

Lilo t'o nlo o mu iyawo 'elo!

K'a wi 'a fo, nwon wa ile

Nwon ko ri Omo'mi at'aya re mo!

Ologbon nda, onimoran

Nwon ni, “Enia ti se wo'le larin agbo!

E ma gbe ile n'beun"

Nigbati nwon wa gbe'le na tan

Eiyele ni won ba tabi adie?

Eni ba s'oju e k'o wa so'tan!

Emi nikan l'o s'oju 'e nijoun

Nijo nwon gbe'le nijoun

Mo mo ohun nwon ba nibe

Ota meji ni nwon ba nibe
At her husband's dismay and an exclamation of "Ha!" He was swallowed up by the ground at Ife.

His departure also claimed his wife along!

To say the least, the hunters began to search the ground for them They couldn't find Omowonmi and his wife; not again!

The wise gave their counsels

They marveled, "How can the forest swallow one up!

Dig the ground yonder!"

After they were done digging;

Are they able to find a bird or a human?

Whoever witnesses this should recant the story!

I am the only witness

When they dug the ground in those days

I knew what they found

They found two enemies 
Ota on l'o wa tun pada

Di ohun ode nmu re igbo-ode titi d'oni

Oko t'o wo'le ni ota,

Iyawo re ni ahaya!

$\mathrm{Ni}$ awon obinrin se enu koto

Orin awo ko si won lenu,

Nwon wa nkorin bayi pe:

Obiri-biri, ota wo'le o

Ao r'Omo'mi nile yi mo, ota wo'le

Obiri-biri, ota wo'le o

Ao r'Omo'mi nile yi mo, ota wo'le

Obiri-biri, ota wo'le o
It's the enemy that came back

The hunter went into the forest with him

up to now

The husband that was swallowed up was

the enemy

The wife was ahaya

The women were aghast

These songs were not far from their mouth

They sang this way, thus:

A woman, a woman, an enemy is

swallowed up

Omowonmi can't be found in the town

again. The enemy is swallowed up

A woman, a woman, an enemy is

swallowed up

Omowonmi can't be found in the town

again. The enemy is swallowed up

A woman, a woman, an enemy is

swallowed up 
Ao r'Omo'mi nile yi mo, ota wo'le

Obiri-biri, ota wo'le o

Obiri-biri, ota wo'le o

Ao r'Omo'mi nile yi mo, ota wo'le"
Omowonmi can't be found in the town again

The enemy is swallowed up

A woman, a woman, an enemy is

swallowed up

Omowonmi can't be found in the town again

The Ijala tale above makes us understand that the hunter, Omowonmi, works all day, and to his utter dismay, his wife disgraces him by serving his food with her left hand. There are two main ideas in the tale: One is that Ijala teaches women certain ways to serve their husband, i.e., how to perform their gender roles; the other idea is that there is a repercussion for any woman who fails to comply or "perform" her duty this way. This Ijala depicts that the Yoruba culture leaves the ability of men to nourish themselves to women. In this tale, a woman is synonymous to a subordinate; thus, we see the asymmetry that typifies the relationship between the husband, Omowonmi, and his wife. Children who listen to tales like this daily automatically and subconsciously pick up on these themes. The roles expected of women and men in the Yoruba culture are exactly what Kaufman (2007) drives home, with the question:

'In the mind of a four-or-five -year-old child who doesn't know about the power of advertising, the state, education, interactive psychological patterns, unequal pay, sexual 
harassment, and rape, what else can he think bestows the reward of masculinity than that little visibility difference between men and women, boys and girls? $?^{58}$,

Insofar as the Yoruba understand these tales to represent ancient events, they impute a sacredness to them that enables them to function as avenues for informing the younger generation on how to perform gender.

In this Ijala tale, the woman becomes the enemy for failing to comply with her "gender roles." Again, just as Oyewumi (1999) observes that the Yoruba uses neuter pronouns for both the sex of women and men, we are unable to verify the sex of the hunter. Hence, we depend on the narrative of Omowonmi as the husband (heterosexual) whose wife serves with her left hand. Olajubu (2003) seeks to express the negative "masculine" stereotypes as foreign to the Yoruba culture. She argues that by claiming that "individuals performed duties expected of them in the society," she contradicts her claim that the principle of domination was not accommodated in the Yoruba culture. ${ }^{59}$ To argue that gendered behavior was not accommodated in the Yoruba culture is to claim that there were no specified roles for individuals. Therefore, by presenting a counter argument that Yoruba gender characteristics are unrestricted, this study is not claiming to

\footnotetext{
${ }^{58}$ Kaufman, Michael. (2007) The Construction of Masculinity and the Triad of Men's Violence. Edited by Laura L. O'Toole, Jessica R. Schiffman, and Margie L. Kiter Edwards, in Gender Violence: Interdisciplinary Perspectives. New York: New York University Press p.43

${ }^{59}$ Olajubu, Oyeronke. (2003). Women in the Yoruba Religious Sphere. USA: State University of New York Press p.43
} 
be obsessed with "theories which attempt to relate the particular to the universal" thereby produce inauthentic African hermeneutics. As demonstrated in this Ijala poem, to claim that gender was imposed on the Yoruba culture is to deny the tale of Omowonmi as authentically Yoruba. Omowonmi's wife's condescension in Ijala led to the breakdown of her relationship with her husband. Ijala in this way represents how women's negotiation with patriarchy is expressed in a reproduction of gendered expressions through their performances. Women's condescension to patriarchy leads to its breakdown. This suggests that the failure of women's negotiation with the patriarchal system leads to chaos.

\section{Gelede}

This section will examine Gelede and its idea of gendered power relation. Gelede means a mask or masquerade performance by men in the honor of the power of women or mothers. To explain why such power is not replicated in the present-day Yoruba, Lawal (1996) addresses women's position of power in the ancient past, claiming that women occupied positions of power currently occupied by men. Lawal claims that women willingly relinquish their position of power. ${ }^{60}$ While the Yoruba always offer reasons for events, it is problematic to agree with the claims that Yoruba women give up their power willingly. Lawal's claim questions the so-called power of women. Lawal's assertion raises questions. The performance of Gelede by men today could have accounted for and supported the assertion by Lawal. However, there was no evidence that women wore the Gelede mask in the past, which is now exclusively worn by men. Perhaps, women held

${ }^{60}$ Lawal, Babatunde (1996). The Gẹ̀lẹdé Spectacle: Art, Gender, and Social Harmony in African Culture. Seattle: University of Washington Press p.267 
both the subordinate and powerful positions in the past rather than hold an exclusively powerful position.

Consequently, Gelede's recognition of "the powerful mothers" may be exclusive. For, in Ekun Iyawo, this study shows that the new bride contends with her new family hierarchy in negotiating with patriarchy. The Drewals (1990) also support the claims that despite women's economic independence in their husbands' homes, since they are strangers in their matrimonial homes, their power is very limited. In other words, there are two kinds of women in the Yoruba household, the subordinate woman and the "powerful" mothers. ${ }^{61}$ This study therefore submits that the celebration of the "powerful mothers" is exclusive.

The Drewals (1990) report the following Gelede chant:

Honor, honor, honor today, honor to the deities

Honor to Ogun Onire, my husband

Ogun the brave one is firing, in firing

Ogun left $\{$ killed $\}$ his wife in the bathroom

Ogun killed the swordsmen

He destroyed them with one blow

Ogun, I asked you to chase them, not to lick their bones

Honor to the one whose penis stood up to father a child in the room

He made his penis lengthen to father a child in the house of Ijana

We heard how the penis struck those in the market

${ }^{61}$ Drewal, Henry John. $(1990 ; 1983)$. Gẹlẹdẹ: Art and Female Power among the Yoruba. Bloomington, IN Indiana University Press p.53 
Ogun, the one who saw the King's mother and did not cover his penis

Esu Laroye, the one who weeps with tears of blood

When one began to excrete feces, you frighten them by excreting intestines

Honor, oooo \{elongation of particle used in greeting to indicate respect , honor today

oo

Odulebe \{destructive mother\}, I, I honor you today

Old bird did not warm herself in the fire

Sick bird did not warm herself in the sun

Something secret was buried in my mother's house

A secret pact with a lizard ni jennejenne

Honor, Honor today, ooooo

Honor to my mother opake na nake nake nake, eeeee

Opake na nake, nake, nake

Mother whose vagina causes fear to all

Mother whose pubic hair bundles up in knots

Mother who sets a trap, sets a trap

Mother who had meat at home in lumps. ${ }^{62}$

In the Gelede praise above, Ogun's masculine power receives some praises that focus on his ability to use his "man power" (penis) without intimidation, even in the presence of the King's mother. We also notice that the chant for the praise of the "woman's power" is also there complementing the men. The chanter of this verse wants

${ }^{62}$ Drewal, Henry John. (1990; 1983). Gẹlẹdẹ: Art and Female Power among the Yoruba. Bloomington, IN Indiana University Press p.42 
us to focus on the sexual prowess of both men and women as a measure of their equality. In this way, Gelede seeks to suggest that when it comes to sexuality there is a balance in the relationship between women and men. One is not superior or inferior to the other. One intriguing insight we can glean from this Gelede is that Ogun, a deity, epitomizes male sexual prowess. This prowess is reflected in Ogun's violent "firefighting” (sexual) attributes. In the same vein, the woman's sexual prowess could intimidate a man as suggested by Gelede; it causes fear to all (men).

Therefore, Ijala, which is chanted or recanted by men, relays men and women's relationship in a hierarchical way. Gelede, which is also chanted and performed by men, does not convey a hierarchical relationship. Rather it communicates equality. What Ifa and other genre sources say so far is that Yoruba gender ideology varies depending on the genre and its message and is not confined to a specific analytical construct.

\section{Conclusion}

Women in the oriki are presented and represented in a variety of ways. They are presented through iwa as a body of ideas and through ekun iyawo as subservient to men. Yoruba people experience patriarchy differently depending on their gender and class. While in some cases, patriarchy tends to favor older women, younger women, like newly wedded brides represent the lowest order in the Yoruba class ranking in the family. This order of ranking shapes the consciousness of a number of women who bargain with patriarchy as a means of survival. Resistance requires endurance. Women in ekun iyawo demonstrate their endurance of the cultural system. Iwa however, presents the reverse side of the same coin. She is the epitome of what an ideal woman should be-someone in control of herself. Iwa as a body of ideas represent what the 
Yoruba culture demands of both men and women. Once Orunmila violates her, she absconds. The fluidity and the dynamism in both stories suggest that the Yoruba tradition is not monotone. For patriarchy to persist, women must be its instrument, but for it to dissolve, women and men have a role to play. 


\section{CHAPTER VII}

\section{Conclusion}

In concluding this study, I merge the central argument and its strands in this chapter. Gleaning insights from primary and secondary sources, this study has argued that Yoruba sacred oral texts demonstrate how Yoruba women challenge, resist, and endure a world dominated by patriarchy and its values. It was important to engage the Yoruba oral genres because they provide a deeper and broader ideological context in which we can examine Yoruba understandings of their world, especially the place of women and their access to power in this male dominant world. My goal has been to show that whenever Yoruba women negotiate with patriarchy, they face and must endure resistance from patriarchy. The resistance women must endure stems from the values and practices linked with patriarchy. These reinforce the roles that women and men play in Yoruba society. Patriarchy challenges men, too. However, in meeting the demands of patriarchy, women pay more dearly in their act of negotiating its values and practices.

The questions raised by the oral genres explored mostly center around women's response to their marginalization. For example, while women openly resist patriarchy in the ekun iyawo, by lamenting, they also exude a sense of helplessness because of the marital obligations Yoruba patriarchy requires them to fulfill. The problem Yoruba women face is not so much about their being denied access to power. It is more about the cost of getting that power, how they must navigate uncomfortable terrains in their bid to access power. For instance, as demonstrated in the study, Moremi had to use her sexuality, albeit reluctantly, to liberate her town, Ife, from Igbo domination. Yet, despite 
her act of courage, Moremi is derided for promiscuity. Osun also had no choice but to intimately engage with Esu in order to access the knowledge of a special act and art of divination. Similarly, the aje had to endure domination of their power, which was manipulated by both Orunmila and Obatala. However, despite their perceived marginalization, some of the women were still able to stand their ground by choosing not to be subservient. Thus, Iwa evokes a very strong woman's presence by standing her ground in the negotiation. However, in the proverbs we see how patriarchy prescribes behavioral codes women must uphold. All these prescriptions go into shaping how the Yoruba ideology of gender is enacted.

One implication of the research findings, thus far, is that some of the highlighted Yoruba traditions in this study still shape how they perform gender. The cultural and religious values are intertwined, informing Yoruba gender ideologies. The themes in each genre suggest that the Yoruba notion of gender is not monotone. This is seen in the two ways of interpreting Iwa as both genderless and gendered. These two ways are suggestive of the need for more investigation in both areas. Oyewumi's (1997) focus was on how Yoruba gender ideologies are invented and not originally Yoruba. Her focus was hinged on the fact that there were no tangible evidences to qualify them as authentically Yoruba from the gender neutrality of the Yoruba language. Matory (1994) was able to relate both Ogun and Sango in a relational gendered sense by identifying how both men and women who function as priests and priestesses of the possessing Orisa are "wives" of the Orisa. In this way, the hegemony of "husbands" is located in men. Thus, the gender hierarchy portrayed in the literal sense is that husbands exist at the apex of authority over their wives. 
This study links the Yoruba oral tradition together by weaving their symbolic and the non-symbolic nature and arriving at their nuanced meanings. In this way, this study submits that the Yoruba tradition is not monotone because there are multiple ways to examine Yoruba values and practices. The non-monotonous attributes of the Yoruba tradition lead us to more research in areas not limited to Feminist or Gender studies. Crucial here is an important insight that has relevance beyond gender relations. Similar to the theme of racial politics in Latin America that understands the inclusion of blacks into the nation as contingent, unstable, cyclical, etc., an examination of how power doesn't operate solely by exclusion, but by conditional inclusion, is a significant theme this study is leading to. Also, the question of Yoruba's prior connections with other traditions and how these have influenced the culture both in and outside of Nigeria is important. In addition, the origin and the connection of practices such as female genital mutilation, and magun (do not mount) to the Yoruba religious understanding will be an important line of research. Finally, an examination of how some of the gender practices are replicated or renegotiated in the African diaspora, will also be a significant line of research inquiry. 


\section{REFERENCE}

Aaron Carter-Ényì. (2018). "Lùlù fún wọn": Oríkì in Contemporary Culture. Ethnomusicology, 62(1), 83-103. doi:10.5406/ethnomusicology.62.1.0083

Abimbọla, Wande. (1975). Yoruba Oral Tradition: Selections from the Papers Presented at the Seminar on Yoruba Oral Tradition, Poetry in Music, Dance and Drama. Yoruba Oral Tradition: Selections from the Papers Presented at the Seminar on Yoruba Oral Tradition, Poetry in Music, Dance and Drama. Nigeria: Dept. of African Languages and Literatures, University of Ifẹ

Abimbọla, Wande. (1977). Àwọn Ojú Odu Mẹerẹệì̀ndínlógún. Ibadan: Oxford University Press, Ibadan

Abiodun, Rowland. (2001). Hidden Power: Osun, the Seventeenth Odu. Edited by Murphy, J. M., \& Sanford, M.-M. (2001). Osun Across the Waters: A Yoruba Goddess in Africa and the Americas. Bloomington: Indiana University Press. Retrieved from http://ezproxy.fiu.edu/login?url=http://search.ebscohost.com/login.aspx?direct=tr ue $\& \mathrm{db}=$ nlebk \&AN=66581\&site $=$ ehost-live $\&$ scope $=$ site

Abiri, J.O.O. (1970). "Mọremi, an epic of feminine heroism." Onibonoje Press: Ibadan

Ahmed, Sara. (2007). Multiculturalism and the Promise of Happiness. New Formations

Amadiume, Ifi. (1947). Reinventing Africa: Matriarchy, Religion and Culture. London, New York: Zed Books

Aaron Carter-Ényì. (2018). "Lùlù fún wọn”: Oríkì in Contemporary Culture. Ethnomusicology, 62(1), 83-103. doi:10.5406/ethnomusicology.62.1.0083

Adams, Robert. (1886). Wife Beating as a Crime and its Relation to Taxation: Read at a Meeting of the Association, April 15th, 1886 by Hon. Robert Adams, Jr., A.M., Bachelor of Finance, Wharton School. Philadelphia: Philadelphia Social Science Association

Ahmed, Sara. (2007). Multiculturalism and the Promise of Happiness. New Formations.

Awe, Bolanle. (1974). Praise Poems as Historical Data: The Example of the Yoruba Oríkì. Africa: Journal of the International African Institute, 44(4), 331-349. Retrieved from http://www.jstor.org.ezproxy.fiu.edu/stable/1159054

Babalola, S. A. (1964). The Characteristic Features of Outer form of Yoruba Ijala Chants. Odu, 1, 33-44. Retrieved on https://www.worldcat.org/title/characteristic-featuresof-outer-form-of-yoruba-ijala-chants/oclc/37462455\&referer=brief_results

Babalola, S. A. 1966. The content and Form of Yoruba Ijala. Oxford, Clarendon P.

Badejo, Diedre. Osun Seegesi. (1996). The Elegant Deity of Wealth, Power, and Femininity. Trenton, N.J: Africa World Press 
Barber, Karin. (1991). Barber, Karin. I could Speak Until Tomorrow: oriki, women and the Past in a Yoruba Town. Edinburgh: Edinburgh University Press for the International African Institute

Barber, Karin. (1984). Yoruba "Oriki" and Deconstructive Criticism. Research in African Literatures, 15(4), 497-518. Retrieved from http://www.jstor.org.ezproxy.fiu.edu/stable/3819347

Bascom, William Russell. (1991, c1969). Ifa Divination: Communication between Gods and Men in West Africa. Bloomington: Indiana University Press

Bascom, William. (1981). Perhaps Too Much to Chew? Western Folklore, 40(4), 285298. doi:10.2307/1499711

Beier, Ulli. (1996). The Origin of Life and Death: African Creation Myths. London, Ibadan Heinemann

Beier, Ulli. (1980). Yoruba Myths. Illustrated by Georgina Beier. Cambridge; New York: Cambridge University Press

Butler, Judith. (1988). Performative Acts and Gender Constitution: An Essay in Phenomenology and Feminist Theory. Theatre Journal, 40(4), 519-531. doi:10.2307/3207893

Bryant, Margaret M. (1945). Proverbs, and how to Collect them. Greensboro, N. C., American Dialect Society

Bryant, Margaret. (1944). Collecting Proverbs. Hoosier Folklore Bulletin, 3(2), 36-36. Retrieved from http://www.jstor.org.ezproxy.fiu.edu/stable/27655481

Carole R. McCann and Seung-kyung Kim. (2017). Feminist Theory Reader: Local and Global Perspectives. London: Routledge. Taylor \& Franics Group

Clarke, J. (1939). Ifa Divination. The Journal of the Royal Anthropological Institute of Great Britain and Ireland, 69(2), 235-256. doi:10.2307/2844391

Collins, Patricia. (2000). Gender, Black Feminism, and Black Political Economy. The Annals of the American Academy of Political and Social Science, 568, 41-53. Retrieved from http://www.jstor.org.ezproxy.fiu.edu/stable/1049471 Accessed on $12 / 3 / 2018$.

Connel R.W. (1987). Gender and Power: Society, the Person and Sexual Politics. Califonia: Standford University Press

Cornwall, Andrea. (2005). eds. Readings in gender in Africa. Bloomington: Indiana University Press: James Currey

Courlander, Harold. (1973). Tales of Yoruba Gods and Heroes. Greenwich, Conn: Fawcett Publications

Coward, Harold G. (1988). Sacred Word and Sacred Text: Scripture in World Religions. Maryknoll, N.Y. : Orbis Books 
Diedre, Badejo. (1996). Osun Seegesi: The Elegant Deity of Wealth, Power, and Femininity. Trenton, N.J: Africa World Press

Drewal, Henry John. (1990; 1983). Gẹlẹdẹ: Art and Female Power among the Yoruba. Bloomington, IN Indiana University Press

Drewal, Margaret Thompson. (1992). Yoruba Ritual: Performers, Play, Agency. Bloomington: Indiana University Press

Ehineni, Taiwo. (2017). From Conceptual Metaphors to Cultural Metaphors:

Metaphorical Language in Yoruba Proverbs and Praise Poems, Language Matters, 48:3, 130-144, DOI: 10.1080/10228195.2017.1406533

Epega, Afolabi A. (1995). The sacred Ifa oracle. San Francisco: Harper

Falọla, Toyin. (1991). Yoruba historiography. [Madison, Wis.]: African Studies Program, University of Wisconsin-Madison

Falola, Toyin \& Genova, Ann. (2006). Orisa: Yoruba Gods and Spiritual Identity in Africa and the Diaspora. NJ \& Eritrea: African World Press, INC

Faniyi, Dejo. (1975). Rara Iyawo. Edited by Abimbọla, Wande. Yoruba Oral Tradition: Selections from the Papers Presented at the Seminar on Yoruba Oral Tradition, Poetry in Music, Dance and Drama. Yoruba Oral Tradition: Selections from the Papers Presented at the Seminar on Yoruba Oral Tradition, Poetry in Music, Dance and Drama. Nigeria: Dept. of African Languages and Literatures, University of Ifẹ

Geertz, Clifford. (1973). The Interpretation of Cultures: Selected Essays. New York: Basic Books.

Gleason, Judith. (1971). Orisha: The Gods of Yorubaland. Canada: McClelland \& Stewart, Ltd

Hallen, Barry. (2000). The Good, the Bad, and the Beautiful: Discourse about Values in Yoruba Culture. Bloomington: Indiana University Press

Idowu, E. Bọlaji. (1994; 1995). Olódùmarè : God in Yorùbá Belief. New York, NY: Wazobia

Ijimere, Obotunde (1966). English adaptation by Ulli Beier. The imprisonment of Obatala, and other Plays. Published: London, Heinemann

James Bode, Agbaje. (2016). A Socio-Cultural Study of Negative Portrayals of Masculinity in the Yorùbá Oral Literature: Yorùbá Proverbs as a Case Study. 1http://www.theartsjournal.org/index.php/site/index

Kandiyoti, Deniz. (2013). Bargaining with Patriarchy. Edited by McCANN, Carole. \& Kim, Seung-Kyung in Feminist Theory Reader: Local and Global Perspectives. New York \& London: Routledge 
Kaufman, Michael. (2007) The Construction of Masculinity and the Triad of Men's Violence. Edited by Laura L. O'Toole, Jessica R. Schiffman, and Margie L. Kiter Edwards, in Gender Violence: Interdisciplinary Perspectives. New York: New York University Press

Kimmel, Michael. (2007). “Contextualizing Men's Violence: The Personal Meets the Political.” Edited by Laura L. O'Toole, Jessica R. Schiffman, and Margie L. Kiter Edwards, in Gender Violence: Interdisciplinary Perspectives. New York: New York University Press

Kolawole, Mary E. Moupe. (1998). Gender Perceptions and Development in Africa. Lagos: Arrabon Academic Publishers

Kunin, Seth. (2006). Theories of Religion: A Reader. Edinburgh: Edinburgh University Press

Laura L. O'Toole, Jessica R. Schiffman, and Margie L. Kiter Edwards. 2007. Edited. Gender Violence: Interdisciplinary Perspectives. New York: New York University Press

Law, Robin. (1984). How Truly Traditional Is Our Traditional History? The Case of Samuel Johnson and the Recording of Yoruba Oral Tradition. History in Africa, 11, 195-221. doi:10.2307/3171634

Lawal, Babatunde (1996). The Gẹ̀lẹdé Spectacle: Art, Gender, and Social Harmony in African Culture. Seattle: University of Washington Press

Lijalu, EM. (1965). Ifa Mimo Alabalase. Ibadan: United Star Printers Ltd

Love, Velma E. (2012). Divining the Self: a study in Yoruba Myth and Human Consciousness. University Park, Pa: Pennsylvania State University Press

Matory, Lorand. (1994). Sex and the Empire That Is No More: Gender and the Politics of Metaphor in Oyo Yoruba Religion. Minneapolis: University of Minnesota Press

Matory, James Lorand. (2005). Black Atlantic Religion: Tradition, Transnationalism, and Matriarchy in the Afro-Brazilian Candomblé. Princeton, N.J: Princeton University Press

Mohanty, Chandra. (1988). Under Western Eyes: Feminist Scholarship and Colonial Discourses. Feminist Review, (30), 61-88. doi:10.2307/1395054

Mudimbe, V. Y. (1988). The Invention of Africa: Gnosis, Philosophy, and the Order of Knowledge. Published: Bloomington: Indiana University Press

Navarro, Marysa. 1999. Women in Latin America and the Caribbean: Restoring Women to History. eds.Marysa Navarro and Virginia Sanchez Korrol, with Kecia Ali. Published: Bloomington, Ind. : Indiana University Press

Nzegwu, Femi. (2001). Love, Motherhood, and the Legacy of Modern Heritage: The Legacy of Flora Nwapa. Dakar: African Renaissance 
Ogungbile, David. (2001). Erìndínlógún: The Seeing Eyes of Sacred Shells and Stones. Edited by Murphy, Joseph M., and Mei-Mei Sanford. Osun Across the Waters: A Yoruba Goddess in Africa and the Americas. Indiana University Press

Olupọna, J. (1993). The Study of Yoruba Religious Tradition in Historical Perspective. Numen, 40(3), 240-273. doi:10.2307/3270151

Olúpònà, J., \& Ajíbádé, Ş. (2005). Ękuń İyàwó: Bridal Tears in Marriage Rites of Passage among the Òyó-Yorùbá of Nigeria. In Patton K. \& Hawley J. (Eds.), Holy Tears: Weeping in the Religious Imagination (pp. 165). Princeton; Oxford: Princeton University Press. Retrieved from http://www.jstor.org.ezproxy.fiu.edu/stable/j.ctv36zq11.13 Accessed on $11 / 19 / 2018$

Olupona, Jacob. (2011). City of 201 Gods: Ile Ife in Time, Space, and the Imagination. Berkeley \& Los Angeles: University of California Press.

Olajubu, Oyeronke. (2003). Women in the Yoruba Religious Sphere. USA: State University of New York Press

Okome, Mojubaolu. 1998. African Women and Power: Reflections on the Perils of Unwarranted Cosmopolitanism. Jenda Journal, Vol 1, No 1 (2001). Available at SSRN: https://ssrn.com/abstract=2761799

Otero, Solimar. \& Falola, Toyin. (2013). Yemoja: Gender, Sexuality, and Creativity in the Latina/o and Afro-Atlantic Diasporas. Albany: State University of New York Press, 2013

Owomoyela, Oyekan. (1988). A Kì í; Yorùbá Proscriptive and Prescriptive Proverbs. Lanham, MD: University Press of America

Owomoyela, Oyekan. (2005). Yoruba Proverbs. Lincoln: University of Nebraska Press

Oyěwùmí, Oyèrónké. (2005). African Gender Studies: A Reader. New York: Palgrave

Oyěwùmí, Oyèrónké (1997). The Invention of Women: Making an African Sense of Western Gender Discourses. London: University of Minnesota Press

Parrinder, Geoffrey. (1967). African mythology. Hamlyn

Parrinder, Geoffrey. (1969). African Mythology. Middlesex: The Hamlyn Publishing Group LTD

Pemberton III, John. 2000. Insights and Ancestry in African Divination. Washington \& London: Smithsonian Institution Press

Petro, A. (2012). Religion, Gender, and Sexuality. In Harvey P., Blum E., \& Stephens R. (Eds.), The Columbia Guide to Religion in American History (pp. 188-212). 
Columbia University Press. Retrieved from

http://www.jstor.org.ezproxy.fiu.edu/stable/10.7312/harv14020.13

Raji-Oyelade, A. (1999). Postproverbials in Yoruba Culture: A Playful Blasphemy. Research in African Literatures, 30(1), 74-82. Retrieved from http://www.jstor.org.ezproxy.fiu.edu/stable/3820474

Welch, David. (1973). Ritual Intonation of Yoruba Praise-Poetry (Oríkì). Yearbook of the International Folk Music Council, 5, 156-164. doi:10.2307/767500

Yemitan, Oladipọ. (1963). Ijala : Aré ọdẹ ti a șe ákójọ rẹ latio ọwọ Oladipọ Yemitan ; [aworan lati ọwọ M.O. Onimọlẹ.Ibadan; New York: Oxford University Press

Scott, James C. (1985). Weapons of the Weak: Everyday Forms of Peasant Resistance. New Haven: Yale University Press

Seth D, Kunin. with Jonathan Miles-Watson. (2006). Theories of Religion: A Reader. Edinburgh: Edinburgh University Press

Sheffield, Carole. (2007). Sexual Terrorism. Edited by Laura L. O'Toole, Jessica R. Schiffman, and Margie L. Kiter Edwards, in Gender Violence: Interdisciplinary Perspectives. New York: New York University Press 